\title{
A GENEALOGY OF SOUTHEAST ASIAN STUDIES IN AUSTRALIA Scholars and Their Works
}

\author{
James J. Fox
}

\section{INTRODUCTION: A CRITICAL PROVISO}

Southeast Asian studies have developed to become a considerable field of Southeast Asia, as Australia's neighbouring region, has study in Australia. Southeast Asia, as Australia's neighbouring encouraged considbeen the focus of national interest and this interest has enceral decades. erable research and teaching in Australian universities been a unified subject Yet "Southeast Asian Studies" as a whole has never been a extricated from of investigation nor can the study of Southeast Asia be exho have made other specific fields of research. Many of the individuals who have nade the greatest contribution to the general field of Southeast Asialar discipline seen themselves primarily as contributors either to a pady such as anthropology, politics, economics or

of a particular country within Southeast Asia.

One might go further and argue that Southeast Asia could well be seen as a "transitory" category created in the period after the
War. Despite the existence of a political foundation through ASEAN for the present conception of Southeast Asia, views 
Although the category of Southeast Asia may be useful for certain purposes, there are other perspectives from which to view this same collection of countries. At different periods of history, various countries within the region have come under the cultural influence of either India or China and it is still possible to distinguish countries within the region accordingly. It is also possible to view these countries in terms of their predominant language families. Thus most of island Southeast Asia forms part of an Austronesianspeaking world. Similarly it is possible to view these countries in terms of their main constituent religions, in which case, Indonesia and Malaysia in particular form part of a Middle Eastern religious sphere.

This chapter offers a "genealogy" of some of the principal contributors to "Southeast Asian Studies" in Australia, even though many of these individuals would not themselves have identified their contribution as primarily directed to the creation of Southeast Asian Studies as such. In Australia, Southeast Asian Studies began through efforts to build disciplinary expertise on particular countries. In some cases, this involved a clear governmentsupported effort. This chapter will therefore proceed by looking first at the founding period and the initial founder figures in particular disciplines. These founder figures were responsible both for educating and recruiting the next generation. The chapter will also examine the institutional framework within which particular individuals carried out their research and teaching, focusing on specific disciplines and the intellectual succession that occurred within these disciplines.

I do this in relation to particular countries in Southeast Asia beginning with Indonesia because of its signal importance to Australia. This combination of discipline and area more closely approximates the way in which Southeast Asian Studies has been organized in Australia. In this chapter, I focus on the individual scholars and cite some of their chief scholarly work. For many versatile and prolific scholars, this thumbnail identification can, I admit, be misleading. I have called this examination a genealogy rather than a history because it provides the bare outline of the complex succession of scholars who together contributed to the creation of Southeast Asian Studies in Australia.

The development of Southeast Asian Studies in Australia is a story within a story. That larger story concerns the development of Australian universities in the post-war period, beginning with the establishment of the Australian National University (ANU) and continuing thereafter with the creation of new universities (Monash, University of New South Wales, Flinders, Griffith and Murdoch), all of which in varying degrees were open to the pursuit of studies on Southeast Asia.

\section{THE FOUNDATION PERIOD: THE FIRST GENERATION FROM 1955}

Four universities figured in the initial development of Southeast Asian Studies in Australia. They were the Australian National University, Sydney University, Melbourne University, and Monash University. Sydney and Melbourne were long established centres of learning in Australia. The Australian National University and Monash University were founded after the Second World War. The Australian National University was established in 1946 with a special charter that required a focus on Asia and the Pacific. The ANU's focus on Southeast Asia was given impetus when it was merged with Canberra University College in 1961. It was also in 1961 that Monash was founded in Melbourne and began its initial efforts to create a Southeast Asian focus.

Although the University of Queensland never established a full-blown Southeast Asia studies programme and instead concentrated, from the mid1950 s, on the study of the history of the region, it could also be included among universities that initially contributed to the development of Southeast Asian Studies in Australia.

\section{THE AUSTRALIAN NATIONAL UNIVERSITY}

The Australian National University was established in the immediate postwar period as a grouping of Schools within the Institute of Advanced Study. Among these Institutes was the Research School of Pacific Studies. "Pacific", at this time, was conceived of, according to one of the University's founders, as ranging "from the Americas to India". The anthropologist, Raymond Firth, was invited to be a member of the planning council of the University and was offered the position as the first Director of the Research School of Pacific Studies.

Although better known for his initial research on the Pacific, Firth had done research in Malaya and, had he accepted the position as Director, he might have contributed impressively to Southeast Asian Studies in Australia. When he declined the position, the task of shaping the School fell to others with different interests. Initial research focused on Papua New Guinea, the Pacific Islands, Aboriginal Australia and, within Asia, on China and to a lesser extent Japan. It was not until Professor Wang Gungwu was appointed as Director of the Research School in 1975 that research on Southeast Asia began to develop rapidly. 
At the time of the founding of the ANU, Canberra already had a "Canberra University College" which was affiliated with Melbourne University. Eventually in 1961, this College was merged with the ANU to become The School of General Studies. Already in 1952, a School of Oriental Languages was established within the Canberra University College and Professor Hans Bielenstein was appointed as its Chair. The initial Oriental languages taught within this School were Chinese, Japanese and Russian.

After the merger with the ANU, Bielenstein's Department became the Faculty of Oriental Studies and continued as such until 1970 when its name was changed to the Faculty of Asian Studies. For a period, Oriental Studies and the Department of Far Eastern History in the Research School of Pacific Studies formed the "Centre of Oriental Studies" at the ANU.

\section{THE ESTABLISHMENT OF INDONESIAN STUDIES IN AUSTRALIA}

In 1955, during Prime Minister Menzies' government, the Commonwealth Office of Education wrote to three universities in Australia offering funding for Indonesian and Malayan Studies. The three universities to which this money was offered were: the Australian National University (more specifically, Canberra University College with its already established School of Oriental Languages), Sydney University and Melbourne University. Each of these universities took a different pathway for developing these studies.

In some government circles, expertise on Indonesia, Australia's neighbour to the north, was felt to be vital for future relations, even though in academic circles, there was preference to continue to develop a more traditional Orientalist focus on China, Japan and India. ${ }^{2}$ Thus, for example, the Canberra University College submitted an alternative proposal for Indian Studies but the Office of Education insisted on Indonesian Studies. Finding suitable staff to build such a programme was, at the time, a considerable task.

Professor Bielenstein, a China scholar, was given this recruitment task in Canberra and he decided upon a young scholar, Anthony H. Johns, trained at the School of Oriental and African Studies in London who was at the time teaching in Indonesia. It took over two years before Johns could conclude his contract and come to Australia. He arrived in 1958 and in 1960, as the ANU-CUC merger was occurring, began the recruitment of a remarkable group of Indonesians who provided the basis for the teaching of the Indonesian language as the first Southeast Asian language to be taught at the ANU.
In 1956, in the initial phase of the Indonesian teaching programme, lectures in Bahasa Indonesia were given at the College by the Cultural Attaché, Mr Supangkat, of the Indonesian Embassy in Canberra. In 1957, for a period of two years, the Indonesian government provided a member of the Indonesian Ministry of Education, Mr Amir Hamzah to teach Indonesian language.

\section{DEPARTMENT OF INDONESIAN LANGUAGES IN CANBERRA: FROM PHILOLOGY TO LITERATURE}

Anthony H. Johns was a key figure in the development of Southeast Asian Studies at the ANU. In 1964, he was appointed as Professor of Indonesian Languages and Literature. He was a seminal figure in the training of successive generations of Indonesianists who did major research on Malay, Indonesian, Javanese and Balinese. He was also a scholar with a deep interest in Arabic and he was critical in directing researchers to the study of Islam in Southeast Asia. Remarkably, as Emeritus Professor, he continues to carry on his research and to advise students at the ANU to the present.

In his inaugural lecture as Professor, Johns noted that "philology for its own sake has dominated Indonesian studies" and that he intended to foster an effort that would lead to a wider purview of Malay and Javanese literary traditions: "...philology is a good servant, but a very bad master". Johns trained students who adopted this view. All of his initial appointees as teaching staff were Indonesians who could provide ANU students with a solid grounding in Indonesian and Javanese and all of them went on to produce major works of their own. S. Soebardi who was appointed in 1961, Soewito Santoso who was appointed in 1964, and Soepomo who was appointed in 1970 all produced nuanced studies of important Javanese texts: Soebardi: The Book of Cabolèk (1975), Soewito Santoso: Sutasoma: A Study in Javanese Wajrajana (1975), and Soepomo: Arjunawijaya: A Kakawin of Mpu Tantalar (1977). The noted writer and author of Atheis, Achdiat Miharja was also appointed in 1961 and he was joined in 1975 by Yohanni Johns who went on to produce what became for many years the most popular textbook for learning Indonesian in Australia, Bahasa Indonesia: Langkah Baru, A New Approach. ${ }^{3}$

\section{DEPARTMENT OF ECONOMICS IN CANBERRA}

Another founder figure at the ANU was Heinz Arndt in Economics. Like Johns, Arndt was originally a member of the Canberra University College 
and became part of the Australian National University at the time of the merger of the two entities. While Johns was located in the "Faculties" at the ANU, Arndt became the Head of Economics in the Research School of Pacific Studies. In this position, he went on to establish the study of the Indonesian economy in Australia but, as he himself recounts (Arndt 1985), this was initially a formidable task. In fact he was strongly discouraged from undertaking such work because of the state of the Indonesian economy during the chaotic, inflationary phase of the Sukarno government in late 1964. He nonetheless visited Indonesia and made contact with the group of economists, popularly known as the "Berkeley Mafia", who later became ministers in the Soeharto government.

With a grant from the Ford Foundation and the editorial assistance of Ruth Daroesman, he was able to publish the first issue of the Bulletin of Indonesian Economic Studies - an eighty-page offset-print produced by the printery of the Research School of Pacific Studies that appeared in June 1965. The Bulletin as a journal continues today in more or less the same format and is certainly one of Arndt's notable achievements. The Bulletin appears three times a year and each year includes a "Survey of Recent Developments" in the Indonesian economy. Arndt produced seventeen of these surveys in the early days of the journal's existence, which required him to make frequent visits to Indonesia. From 1966, he visited Indonesia four or five times a year, staying for three to four weeks to write his survey.

In building a programme on Indonesia and then more widely on Southeast Asia, Arndt recruited to his department a number of research scholars. Three individuals were particularly important: David Penny who came from Cornell University with a strong rural sociology background to do research on Indonesia, R.M. Sundrum who came from Rangoon University and did research on a range of countries, and E.K. (Fred) Fisk who arrived from the University of Malaya.

Penny's 1964 thesis at Cornell was on the transition from subsistence to commercial farming in North Sumatra. At the ANU, he developed a productive collaboration with Masri Singarimbun in the study of Javanese village poverty in a site known as Sriharjo (Penny and Singarimbun 1973). Sundrum's appointment led to a long and varied career in the Department of Economics and collaboration with different colleagues, including Arndt. A good example of their early collaboration was a short monograph they did together on transmigration in Indonesia (1977). Fisk's work, like Penny's, had a rural focus. In 1964, he published a book on the rural economies of Southeast Asia and in his early years in the department edited two books on Malaya/Malaysia with different colleagues (Fisk and Silcock 1963; Fisk and Osman-Rani 1982). Thomas Silcock, Fisk's first collaborator on Malaya, was a Visiting Fellow in Economics. He was a fluent Thai-speaker and was was a res well as a study of Thai agriculture (1970). He maintained a productive association with the department and continued to work on Thailand.

\section{ANTHROPOLOGY IN THE RESEARCH SCHOOL OF PACIFIC STUDIES AT THE ANU}

Another less prominent but nonetheless important founding figure in a genealogy of Southeast Asian Studies at the ANU was Derek Freeman. Trained in London and at Cambridge University, Freeman wrote one of the finest ethnographies of its kind on the Iban of Sarawak. ${ }^{4}$ Until his retirement, his work continued to attract students interested in the Iban in particular and in Borneo in general but not long after his arrival in Canberra in 1955 , he turned his attention to Samoa where he had done previous research and then to issues in the intersection of anthropology and biology.

The founding Professor of Anthropology was Siegfried Nadel who died suddenly in 1956 and was replaced by John Barnes who was already a Professor at Sydney University. Barnes took upon himself the task of requiring students to do research on Indonesia and thus Anthropology was among the first departments to produce Indonesianist graduates, all of whom did research on Sumatra. Donald Tugby received his Ph.D. in 1960 for research on the Mandailing Batak; Mervyn Jaspan in 1964 for research on the Rejang; and Masri Singarimbun in 1965 for research among his own people, the Karo Batak.

Masri Singarimbun was a remarkable individual who not only published a "classic" study on the Karo (1975); he also collaborated in early work with the rural economist, David Penny. More significantly, he stayed on in Canberra to train himself as a demographer. When he returned to Indonesia, he was able to establish the Population Studies Centre (Lembaga Kependudukan) at Gadjah Mada University which became a significant centre for research, particularly on Java. Toward the end of his career, the ANU awarded him an Honorary Doctorate for his many achievements.

Another early graduate of this period who combined archaeology and anthropology was Campbell Macknight who wrote his thesis (1969) on the Macassan trepang industry in Northern Australia. The book based on his thesis was published in 1976; he went on to do substantial research, at the ANU and later in Tasmania, on the Bugis of South Sulawesi. 
Gehan Wijeyewardene joined the Anthropology Department in 1964 with a research background in Ceylon. However, he soon shifted his interests to northern Thailand and created the long-standing Thai-Yunnan Research Project.

\section{ARCHAEOLOGY AND PREHISTORY AT THE ANU}

Almost from the outset, archaeological research of various kinds was carried out in different parts of the ANU: through a Prehistory Department that separated from Anthropology in the Research School of Pacific Studies, through a Department of Prehistory and Anthropology in the Faculty of Arts and by particular individuals in the Faculty of Asian Studies. This research focused on very different time periods: ranging from the early Pleistocene to the late Pleistocene and Holocene and into the classical period of Southeast Asian kingdoms.

The first ANU archaeological research in Southeast Asia was carried out by English students, J. M. Matthews and Ian Glover. Matthews wrote a thesis in 1964 on "Hoabinian" in Southeast Asia. Glover, on the other hand, carried out extended excavations in what was then Portuguese Timor in 1966-67. Two years later, in 1969, John Mulvaney, in cooperation with the Indonesian archaeologist R.P. Soejono who had been a visitor to Canberra the year before, led a major expedition to South Sulawesi, bringing with him Macknight who had just finished his Macassan thesis and Glover who was still working on his. Much of this initial research set a pattern for the future.

Glover finished his thesis in 1972 and published the major monograph on this work in 1986. On taking up a position at the Institute of Archaeology in London, Glover excavated adjacent sites to the first ANU sites and produced a number of studies establishing a long sequence for the area.

Helmut Loofs-Wissowa who had joined the Faculty of Asian Studies was at this time beginning his ANU career focusing on the classical archaeology of mainland Southeast Asia. In 1970, he published a basic volume on Vietnamese archaeology.

\section{HISTORY IN THE RESEARCH SCHOOL OF PACIFIC STUDIES AT THE ANU}

The history of Southeast Asia had its first hesitant beginnings in the study of British colonial history and as a consequence there was to begin with more interest in Malaya than with Indonesia. Much depended on an initial cohort of graduates. Emma (Emily) Sadka who came to the ANU in 1954 from Singapore as a Ph.D. student and wrote her thesis on the residential system in the protected Malay states (1960) was invited by the founding professor in History, Jim Davidson, a specialist on the Pacific, to assist him in developing a focus on Southeast Asia. She was instrumental in training a number of Ph.D. graduates to do this research. Among them were William Roff, Chris Wake and Chris Penders.

Roff did his thesis (1965) on the origins of Malay nationalism, which was published as a book in 1967; he went on to have a distinguished research career which focused on the study of Malaysia. Wake's thesis (1966) looked at nineteenth-century Johore but was never published as a book. Penders wrote his thesis (1968) on Dutch colonial education policy and practice in Indonesia in the first part of the twentieth century and continued to publish regularly on the colonial period and some of Indonesia's key nationalists. He took up an appointment at the University of Queensland where he continued the tradition begun by Bastin and Tarling, focusing on the history of Southeast Asia.

When Sadka died unexpectedly in 1968, Davidson recruited the Oxfordtrained Indianist, Christine Dobbin as a research fellow. She turned her attention to Indonesia and published a number of studies, including an excellent examination of the Padri war (1983).

\section{DEMOGRAPHY IN THE RESEARCH SCHOOL OF SOCIAL SCIENCE AT THE ANU}

Demography at the ANU established the beginnings of a Southeast Asian interest through the training of its students. Jack Caldwell, who pioneered the development of demographic research in a wide spectrum of directions, wrote a thesis on the population of Malaya in 1962. He was joined in the Department by Gavin Jones who wrote his thesis on labour in Malaya in 1966. Together these two figures became a mainstay of the Department of Demography into the 1990s. Jones' work on an array of issues in the demography of Indonesia and of Southeast Asia (1984, 1994) laid a strong foundation for this field. In the early days of the Department, however, Jones and Caldwell were responsible for recruiting Masri Singarimbun as a research fellow to work on the demography of Indonesia. This led to a close relationship between demography at the ANU and what was to develop as the Population Institute in Yogyakarta. 


\section{INDONESIAN STUDIES AT SYDNEY UNIVERSITY}

As in the case of the ANU, Indonesian studies at Sydney was begun through initial funding from the Commonwealth. At Sydney, it was decided to use these funds to establish a separate Department of Indonesian and Malayan Studies and to appoint as Head of this Department a notable scholar of Old Javanese, F.H. van Naerssen, who had been trained in Leiden, and later a young expert on Malay texts, Russell Jones who had been trained at the School of Oriental and African Studies. Both were oriented to the philological study of texts and their two most notable students, Peter Worsley and Stuart Robson carried on and extended this tradition. As students both Worsley and Robson did their Honours degrees at Sydney but went on to do their Ph.D.s at Leiden. Robson reworked his Sydney MA on the Classical Malay text, Hikajat Andaken Penurat, publishing it in 1969 and thereafter did his major work on Javanese. Worsley did his doctoral work on a Balinese dynastic genealogical text, the Babad Buleng which he published in 1972. He returned to Sydney as Professor and was responsible for promoting research on Bali and the Balinese. Robson remained in Leiden after the completion of his degree; he produced critical editions of a number of important Javanese texts, among others a new translation of the Deśawarnana (or Nãgarakrtāgama) by Mpu Prapañca but also useful materials for teaching colloquial Javanese. He, too, eventually returned to Australia.

In 1967, the Department established a journal, Review of Indonesian and Malayan (later to become Malaysian) Studies, popularly known as RIMA which has continued to the present to be published with two issues each year. It is the oldest continuing journal of its kind in Australia. In 2003, an independent association was formed in Canberra to publish the journal and since that time, the journal has been successfully edited by Campbell Macknight.

In the Anthropology Department at Sydney was W.H. Geddes who, like Derek Freeman, had carried out fieldwork in the British Crown Colony of Sarawak under the auspices of the Colonial Social Science Research Council. ${ }^{5} \mathrm{He}$, like Freeman, wrote a study which is also a classic of its kind, Nine Dayak Nights, a superb account of the recitation of a long Dayak tale. Like Freeman, he also shifted his fieldwork interests to the Pacific but also to Thailand where he did research among the highland Hmong or Blue Miao. He was thus partially responsible for the development of Thai studies at Sydney. One of the first students to take Introductory Indonesian at Sydney was Douglas Miles who went on under Geddes' supervision to do fieldwork among the Dayak of Kalimantan. After the publication of his first ethnography (1976), he followed Geddes' lead in doing further research in northern Thailand and then went on to do research on Bali. Another of Geddes' students was Peter Hinton who continued research on Thailand at Sydney. ${ }^{6}$

Among the first to develop interests in the politics of Southeast Asia at Sydney University was Michael Leigh who did his Ph.D. at Cornell on political leadership in Sarawak in 1967. His first study of Sarawak, The Rising Moon: Political Change in Sarawak, was published by Sydney University Press in 1974. In his long career, Leigh held various positions including a Professorship in Sarawak before being appointed as the Director of the Asia Institute in Melbourne. In the 1970s, Leigh was joined by Michael van Langenberg who completed a Ph.D. thesis at Sydney on national revolution in North Sumatra in 1976. Langenberg continued a tradition of critical analysis at Sydney that was focused on political economy. This was a tradition begun by Rex Mortimer who was appointed at Sydney after obtaining his Ph.D. at Monash in 1970. Richard Robison, another student in this tradition, finished his thesis at Sydney on capitalism and the bureaucratic state in Indonesia in 1979 and moved to Murdoch University in Western Australia where he had a distinguished and prolific career. One of Robison's important early studies was Indonesia: The Rise of Capital (1986); his work became directed to the study of Southeast Asia as a whole. With one of his students, Garry Rodan, he produced The Political Economy of South-East Asia: An Introduction (1997) and followed this with a succession of books on various aspects of the political economy of the region.

\section{INDONESIAN AND MALAYAN STUDIES} IN MELBOURNE

The third bequest of funding from the Commonwealth government for the establishment of Indonesian and Malay studies was made to Melbourne University. Melbourne adopted another model for the development of these studies. As in Canberra, the initial teaching of Indonesian at Melbourne in 1956 was provided and supported by the Indonesian government through the secondment of a member of the Indonesian Ministry of Foreign Affairs, Mr Zainu'ddin. Thereafter, for the creation of its Department of Indonesian and Malayan Studies, the University appointed one of its own scholars, a Melbourne graduate, Jamie Mackie, who had studied at Oxford and had spent two years working as a Colombo Plan expert in 
the Indonesian Planning Bureau. On his appointment in 1958, Mackie set out to establish a programme that would examine Indonesia's political and economic development. The programme included the study of the Indonesian language. Together with J.P. Sarumpaet, Mackie produced an introductory text for the study of Indonesian. Mackie, by his determination to create a broader understanding of Indonesia in Australia, can be considered the first Australian to develop a distinct focus on contemporary Indonesia as a political, social and economic entity.

When, however, Monash University was established in 1961, the historian John Legge was appointed as a foundation professor. He recruited the political scientist Herb Feith to join him in establishing the programme that led to the creation of the Centre of Southeast Asian Studies at this new university. To a certain extent, the Monash Centre was modelled on the Southeast Asia Program at Cornell University. Feith did his Ph.D. at Cornell and Legge had spent time there. They were among the first wave of Australians to make their way to study at Cornell and then return to Australia, thus initiating a long-standing connection between Southeast Asian Studies programmes there and in Australia.

The Centre became a remarkable confluence of scholars of different political persuasions who were nevertheless united in a common interest in Indonesia in particular and the region in general. Besides Legge and Feith, these scholars included Cyril Skinner. Michael Swift from the British Anthropology tradition and Lode Brakel from Leiden's "Indische" studies tradition added to this group. In 1968, Jamie Mackie was lured from Melbourne University to Monash to become the Research Director of the Centre making it the leading centre in Australia for the study of Indonesia and Southeast Asia. Another figure to join this group was Barbara Harvey, an American with diplomatic experience in Indonesia and a degree from Cornell (1974) for a thesis on Islam and rebellion in Sulawesi.

Each of these scholars made notable contributions to the study of Southeast Asia. Legge first gained recognition for his Cornell monograph on central authority and local autonomy in Indonesia (1961), then for his general book on Indonesia (1964) and, most significantly for his political biography of Sukarno (1972). Feith also wrote a Cornell monograph on Indonesian politics (1961) and then followed this with his influential study of the decline of constitutional democracy (1962). Mortimer wrote the first of the Monash Southeast Asia Centre papers on the Communist Party's campaign for land reform (1972) and two years later, produced his major study of Communism under Sukarno (1974). Harvey's monograph on the Permesta rebellion was published in 1977. Mackie's publications were wide-ranging. As Research Director, he published a monograph on Sukarno's Confrontation (1974) and on the Chinese in Indonesia (1976). Skinner provided a contrast in the group. He was the elder of the Monash group and maintained a scholarly tradition of historical and textual analysis focused as much on Malaya as on Indonesia through such works as his edited translation of a rhymed chronicle of the Macassar war (1963) and his monograph on the civil war in Kelantan in 1839 (1966). Michael Swift wrote about Malay peasant society (1965) and Brakel worked on Malay manuscripts (1975). Rex Mortimer was one of the first students to study with Feith; his thesis on the Indonesian Communist Party, completed in 1970, was published in 1974 .

Some years later, David Chandler joined the Monash Centre providing it with greater focus on mainland Southeast Asia, in Chandler's case, Cambodia. His extensive publications $(1972,1983,1996)$ covered the land, people and history of Cambodia.

One of the most useful initiatives begun in 1959 at Melbourne University was the formation of an informal discussion group that extended well beyond academia to include anyone with an interest in Indonesia. The group would meet regularly to discuss current developments in Indonesia and became known as the Contemporary Indonesia Study Group. Eventually the organization for this group shifted to Monash University where it still exists and continues to meet to this day.

\section{SOUTHEAST ASIAN HISTORY AT THE UNIVERSITY OF QUEENSLAND}

The University of Queensland was not a recipient of the initial Australian government funding provided to the universities in Canberra, Melbourne and Sydney. It did not therefore develop a language programme for Indonesian but instead came to focus attention on the study of the history of the region and its politics. The British historian, John Bastin, was the first to teach on Southeast Asian history during a year's appointment from 1955 to 1956 and he was succeeded by Nicholas Tarling who taught at the university until 1965 when he accepted a position in New Zealand. Over his long career, Tarling has been enormously prolific. During his time at Queensland, he wrote on Anglo-Dutch rivalry (1962) and also on piracy and politics (1963) in the Malay world and published a short history of Southeast Asia (1966). Later he was responsible for editing The Cambridge History of Southeast Asia (1992). 


\section{THE TRANSITION TO A SECOND GENERATION AT THE ANU}

At the ANU, two figures of the founding generation were notable for the number of students whom they trained and who then continued their careers in Indonesian studies. These two figures are Professor Anthony Johns and Professor Heinz Arndt.

Professor Johns produced a number of distinguished students who, in turn, contributed to the development of Indonesian, Javanese and Balinese studies. Among these students were scholars who stayed on to teach at the Australian National University: Ann Kumar whose dissertation on Surapati published in 1976 combined both historical and textual analysis, and Ian Proudfoot who wrote his thesis on a tale told within the Mahabharata (1977). Both Kumar and Proudfoot published extensively across a wide range of subjects: thus, for example, Kumar's The Diary of Javanese Muslim (1985) which provides a marvellous glimpse into nineteenth century relations about key figures in Islamic learned society. Proudfoot wrote on early printed Malay books (1993) but also delved deeply into the study of old Muslim calendars (2006).

Other students who did their undergraduate study at the ANU in Indonesian studies went on elsewhere for their further degrees. Heather Sutherland went from the ANU to Yale University where she wrote her thesis on the Javanese priayi that was eventually published in 1979; Barbara Hatley also went on to Yale where she did an MA but returned to Australia to complete her Ph.D. at Sydney University on Kethoprak theatre in Yogyakarta in 1985. The book based on her long study of Javanese performance was finally published in 2008, by which time she had been appointed as the Foundation Professor in Indonesian at the University of Tasmania. Chris Manning, another of these undergraduate students, went on to do his Ph.D. in Economics at the ANU.

In Economics, Arndt produced a significant number of able students: Peter McCawley, Ross Garnaut, Anne Booth, Howard Dick, Hal Hill and Chris Manning, all of whom went on to have distinguished careers. McCawley wrote his thesis on the Indonesian electricity industry in 1971, Garnaut on Australian trade with Southeast Asia in 1972, Booth on Indonesian land tax in 1974, Dick on the Indonesian interisland shipping industry in 1977, Hill on the Indonesian weaving industry in 1979, and Manning on the labour market in Indonesian manufacturing also in 1979.

For a while, all of these scholars were in Canberra and worked together in various ways. Garnaut and Manning co-authored a monograph on
Irian Jaya (1974) which was valuable for its time. Booth and McCawley Irian Era (1981), which Arndt, in his autobiography, A Course through Life (1985, p. 66), considered a coming-of-age for the department in its research on Indonesia.

McCawley eventually left the Department to work first in AusAID and then for the Asian Development Bank. Booth was a productive stalwart of the department for many years writing on agriculture. One of her most important books while she was in the Department was Agricultural Deveimportant books while she was as a Southeast Asian Studies monograph. Dick moved to the University of Melbourne. He published a revised version of his thesis in 1986 and, in 2002, a socioeconomic history of Surabaya, Surabaya, A City of Work, that covers the whole of the twentieth century. Garnaut remained in the Department but turned his attention to China. For several years during the Hawke government, he served as Australian Ambassador to the People's Republic of China. Hill, too, stayed on in the Department. Hill's research looked at Indonesian industry but he also studied the Philippine economy and edited several important volumes on the Philippines and on Indonesian regional economic development. Manning also remained in the Department, continuing to write on labour in Indonesia culminating in his major study in 1998. They were joined by Ross McLeod who had also done a Ph.D. at the ANU. Together the three of them took over, in turn, the running of the "Indonesia Project" at the ANU and in particular, the continuing publication of the Bulletin of Indonesian Economic Studies (BIES), which, in 2012, had reached its 48th volume. The Bulletin has provided an extraordinary record, in many ways unique of its kind, in documenting the development of the Indonesian economy.

\section{DEVELOPMENTS IN THE RESEARCH SCHOOL OF PACIFIC STUDIES}

The Research School of Pacific Studies [later, the Research School of Pacific The ANU and as such, it received its research support in a "block grant" from ANU and as research and its $\mathrm{Ph} . \mathrm{D}$. the Australian government. Its primary task was research programme was considered part of its research effort. Those enrolled for a Ph.D. in the Research School were referred to, at the time, as Research Scholars. The School had a relatively small number of tenured faculty with a large number of "Research Fellows" and "Senior Research Fellows" whose appointments could range from two to five years and could, in some 
instances, be renewed for another five years. This arrangement gave the Research School the capacity to hire outstanding individuals for extended periods of time to concentrate on their research and publications. In addition, the Research School had a strong Visiting Fellows programme that offered scholars support for several months to participate in research programmes within the School.

Several developments in the Research School set the stage for further research on Southeast Asia. One important appointment in 1968 was that of Wang Gungwu, who - though appointed to head East Asian History - was a person with a deep interest and knowledge of Southeast Asia. When he became Director of the Research School in 1975, he actively promoted the development of Southeast Asian Studies.

An important appointment was that of Anthony Reid. He began in Wellington where he had studied with Emma Sadka before moving to Cambridge to do his doctorate on Aceh. Although he was appointed in 1970, he took leave in 1973 for two years to teach at Yale and only returned in 1975. Reid, in particular, maintained a commitment to the study of the whole of Southeast Asia and was intimately involved in promoting interdisciplinary research on the region. While continuing to work on Aceh and Sumatra in general, Reid was an enthusiastic organizer of symposia and maintained a continuing commitment to the history of Southeast Asia. He gained international recognition for his Southeast Asia in the Age of Commerce, 1450-1680 and after leaving the ANU for the University of California, Los Angeles (UCLA) and, later, to become Director of the Asia Research Institute at the University of Singapore, he continued to be a vital figure in Southeast Asian Studies.

One can date the emergence of another generation from the early 1970 s. By this time, a number of students of Johns and Arndt held positions at the ANU and were soon joined by a cohort of graduates from Cornell or Yale along with a few graduates, like Reid, from either Oxford or Cambridge. Thus, for example, in 1972, Lance Castles returned from Yale to a research fellowship in the History Department; Leonard Andaya and Rey Ileto arrived in 1973-74. They were the first Cornell appointees to history, though Herb Feith had himself held a position briefly in the Research School before moving to Monash.

Leonard Andaya was accompanied by his wife, Barbara Watson Andaya. She had been educated at Sydney, did her MA at Hawai'i, submitted her Ph.D. at Cornell in 1975 and took up a position at the ANU in 1977. Leonard's study of the kingdom of Johor (1975) and Barbara's study of Perak (1979) were a beautifully complementary set of early historical studies.
Indicative of this new effort was a symposium held in Canberra in April 1973 and published in 1975 on "Pre-colonial state systems in Southeast Asia". Contributors included a range of young scholars: Reid, Castles, Worsley who returned to Sydney to take over the Department of Indonesian and Malayan Studies, Dobbins who was teaching at Flinders, Leonard and wife Barbara Andaya, Campbell Macknight who was lecturing in history the ANU and students such as Virginia Matheson Hooker who was doing her Ph.D. at Monash and Alfons van der Kraan who was doing his at the ANU.

Virginia Matheson Hooker, a graduate of Monash University, was later appointed in Anthony John's Department; she cooperated with Barbara Andaya to produce an annotated translation of the Tuhfat al Nafis, entitled The Precious Gift (1982), which was inspired by Johns' early study, The Gift Addressed to the Spirit of the Prophet (1965). She went on to write a perspicacious examination of the development of the Malay novel (2000) and, together with Greg Fealy, to compile a major source book on contemporary Islam in Southeast Asia: Voices of Islam in Southeast Asia (2006).

In 1975, when Wang Gungwu was appointed Director of the Research School there was beginning to emerge a critical mass of research scholars across several disciplines that was able to attract students interested in studying Southeast Asia.

In 1975, James J. Fox was appointed to a position in the Department of Anthropology and given the explicit task of developing a strong programme on the anthropology of Indonesia. Fox came from Oxford via Harvard with a primary interest in eastern Indonesia, which, at the time, was a region that was hardly studied, despite its proximity to Australia. His first book, Harvest of the Palm (1977), had both an historical and ecological focus on the Timor region and was followed by various comparative volumes on the social structure (1980) and ritual languages (1988) of eastern Indonesia. Soon after his arrival, however, he developed an interest in Java and made this his second area of research. Later, in the 1980s, he initiated the Comparative Austronesian Project at the ANU, thus viewing island Southeast Asia as socially and culturally a distinct part of the Austronesian-speaking world. The Project produced a series of publications that has continued.

David Marr took up a permanent position in History in 1977 adding a focus on modern Southeast Asian history, particularly Vietnam. His work provided a continuing exploration of twentieth century Vietnamese history (1971, 1981, 1995).

Also significantly, in 1978, Jamie Mackie was appointed Foundation Professor in the new Department of Political and Social Change in the 
Research School; he was joined by Ron May who did his research both on New Guinea and the Philippines. As his first staff member, he recruited William O'Malley from Cornell University and not long afterwards, two other recent Australian Ph.D. graduates, Colin Brown and Ken Young for his first major project on Java. Thereafter he hired Brian Fegan to do research on the Philippines, specifically Luzon, to provide a comparative perspective on Java. More importantly, he appointed Harold Crouch whose work on the Indonesian military (1978) and on Malaysian politics (1982, 1996) was particularly notable. At about this same time, both Colin Barlow and Peter Warr were appointed in Economics: Barlow to do research on rubber and other export crops from Indonesia and Malaysia (1978) and Warr on the agricultural development of both the Philippines and Thailand (1993).

Elsewhere in the University, there was also a developing interest in Southeast Asia. Although members of the Demography Department cooperated closely with colleagues in the Research School, it always remained within the Research School of Social Sciences. Its Ph.D. programme was particularly productive at an early date. Peter McDonald finished his thesis in 1972 and in 1975, three more distinguished graduates - Terry Hull, Valerie Hull and Graeme Hugo — submitted their Ph.D.s, all written on demographic issues in Indonesia.

Although McDonald's thesis was on the demography of Australia, he published various substantial works on marriage and divorce in West Java and on the Indonesian census (1983). Hugo's thesis was on population mobility in West Java. He published extensively on the demographic dimension of development in Indonesia and in the Asia-Pacific region (1981, 1987). Both of these researchers went on in their careers to concentrate their attention on Australian demographic development. The Hulls, on the other hand, remained focused on Indonesia and the Asian region. They cooperated and collaborated on research on Java through Masri Singarimbun's Population Institute in Yogyakarta (1976). At the ANU, Terry Hull also published with Gavin Jones (1999) as well as publishing a host of reports on fertility, child mortality and family planning.

In 1973, Anthony Forge was appointed Foundation Professor in Anthropology in the Faculties. Although his major work had been in the Sepik, prior to coming to Australia, he had done a year's fieldwork on Bali, studying, in particular, Balinese art. Fox and Forge had met on Bali and had spent time together so that, once in Canberra, they were able to develop strong cooperation between anthropology in the Research School and in the Faculties. nitially, as a return gesture for Australian Aid under the Colombo Plan, the Thai government supplied a teacher Ajar Wiphut Sophawong . Thai. In 1978, Anthony Diller took (19) Thai on a permanent basis. Diller had done his up a position to teach Thai on a dialect. During his time at the Ph.D. at Cornell on the souther Tistic research, he developed a vigorous ANU, while continuing hage studies.

programme of Thai language studies. Anthony Milner, a graduate of Monash University Ph.D. at Cornell in 1978, returned to Australia in 1980 valties. of Kent at Canterbury to teach in the History Departion broadened to take His early work was on Malay political culture but sont

in a wider range of issues relating to Southerstory and Anthropology

Peter Bellwood in the Department of Prehistory and Anthropolog shifted his in the Faculties, whose first research had been on history of what he called interests to focus on the archaeology an the late 1970s, Margo Lyon was the Indo-Malaysian archipelago (198) Indonesian anthropological appointed in

expertise.

The milestone event at the ANU in the study of Indonesia was a The 1979 that drew on all the The course of Indonesia's expertise throughout the logical beginnings to its most current political and The published as a single economic policies. The results of this seminar were volume, Indonesia: Australian Perspectives (Fox et al. 1980) and as three separate volumes, Indonesia, The Making of a Culture (1980), Indonesia (1980); and, Indonesia: The Making of a Nation (1980)

\section{NATIONAL DEVELOPMENTS IN ASIAN STUDIES FROM THE MID-1970s ONWARD}

The formation of a second generation of Southeast Asianists in Australia 1970s. Australia widened its focus to other countries occurred rapidly in the 1970 s. Austrable effort to develop an appropriate range in the region and made a considerable effort to dudy of scholarly expertise. At the same time, the early efforts to a further scholarly of Indonesia in Australia led to a veritable explosion of expansion of the research on Indonesia. This was in particular a period of

teaching of Indonesia in many universities in Austias

1976 was an important year for Asian Studies in Australia. This was he Asian Studies Association of Australia was founded and 
immediately set to work to promote Asian Studies, including Southeast Asian Studies, in Australia. At the time, the main Asian languages studied in Australia were Japanese, Chinese and Indonesian. In the early 1970s, Indonesian was taught only at Sydney University, Melbourne University, Monash and the ANU. However in 1975, the School of Modern Asian Studies was established at Griffith University in Brisbane and began teaching Indonesian and a year later in 1976, Flinders University in South Australia established an Asian Studies programme featuring Indonesia. For a period in the 1970s, James Cook University in Townsville also taught Indonesian in its Modern Languages programme. This was also the period when a number of variously named Asian Studies or Southeast Asian Studies centres were established in universities. Some of these centres prospered while others failed to reach the critical mass necessary for a viable programme.

The School of Modern Asian Studies recruited Julia Howell from the United States and Robert Elson, one of Legge's students. Howell had an interest in Javanese religion and from this base developed a particular interest in Sufism in Java. Elson proved to be perhaps the most prolific of Indonesian historians, publishing major studies at regular intervals that began with studies on Java's sugar industry and the cultivation system and went on to include a biography of Soeharto and a history of the idea of Indonesia $(1984,1994,2001,2008)$. These two scholars were joined by John Butcher who began his career doing research on the colonial history of Southeast Asia at Hull University (1979) and then moved on to write an important study on the marine fisheries of the region (2004).

Robert Cribb, who did Asian Studies at the University of Queensland before going on to do his Ph.D. at the School of Oriental and African Studies, also taught for a period at Griffith University as well as the University of Queensland. In 2003, he joined the Department of Asian and Pacific History in the Research School of Pacific and Asian Studies at the ANU. His early historical research focused on the revolution in Indonesia: Gangsters and Revolutionaries: The Jakarta People's Militia and the Indonesian Revolution, 1945-1949 (1991). While at Griffith he wrote a modern history of Indonesia with Colin Brown (1995) and at the ANU he produced a Digital Atlas of Indonesian History (2005a).

Other graduates who did their doctoral research in England before taking up positions in Australia were Clive Kessler whose Ph.D. research at the University of London was on the Malaysian state of Kelantan and then, some years later, Kenneth Young whose research, also at the University of London, was on the Minangkabau anti-tax rebellion of 1908. Kessler became an established researcher and commentator on Malaysia at the University of
New South Wales while Young did his research on Indonesia at a number of universities in Melbourne, Canberra and Wollongong. Another graduate with an overseas Ph.D., Jean G. Taylor whose research was done at the University of Wisconsin, has taught for many years at the University of New South Wales. Her splendid book on the social world of Batavia, first published in 1983, was republished in a 2nd edition in 2009.

Graduates of Monash who trained at the Centre of Southeast Asian Studies dispersed throughout Australia. Besides Elson who went to Griffith and Crouch who went to the ANU, Ulf Sundhaussen moved to the University of Queensland, John Ingleson to the University of New South Wales and Charles Coppel to Melbourne University; James Schiller, with his wife Barbara Martin-Schiller, established themselves at Flinders University. Richard Tanter, after teaching in Japan, took up an appointment at the Royal Melbourne Institute of Technology. The anthropologist, Michael Pinches, took a position at the University of Western Australia after completing his $\mathrm{Ph} . \mathrm{D}$, on a shanty town in the Philippines and somewhat later the political scientist David Bourchier who did his thesis on Indonesia also went to the University of Western Australia. Yet another Monash graduate, Damien Kingsbury was appointed at Deakin University. Susan Abeyasekere-Blackburn who wrote her thesis on Indonesian nationalism remained at Monash.

Sundhaussen whose thesis focused on the Indonesian officer corps published his study of Indonesian military politics in 1982; some years later, he and Chris Penders collaborated to write the political biography of Indonesian general, Abdul Haris Nasution (1985). Ingleson published an important study of the Indonesian nationalist movement in 1979 as the first volume in the Southeast Asia publication series of the Asian Studies Association; his study of workers' unions in colonial Java appeared in 1986 as the 12th volume in this series; Coppel's study on Indonesian Chinese published in 1983 was the 8 th volume in the series. He continued to publish on the ethnic Chinese of Indonesia (2002) and on the violence affecting them and others in the country (2006). Schiller's work focused on local government; his wife, whose Monash thesis was on an upland village in Java, joined him in a study of the town of Jepara on Java's north coast (1996).

Tanter's Ph.D. was on the intelligence agencies in Indonesia, an interest which he continued to develop to include the wider Asian region. His research has also been on the politics of the middle class in Indonesia. Bourchier's concerns with Indonesian political thought have also drawn him to research on issues of democracy and dissent in the country. Kingsbury has extended 

his critical research on Indonesia to the Southeast Asian region in general
and to East Timor in particular.

Susan Abeyasekere published variously on the Indonesian nationalist movement (1976) and then wrote a history of Jakarta (1987); later as Susan Blackburn, she did research on a range of feminist issues (2004).

\section{FACILITATING ASIAN STUDIES AT THE NATIONAL LEVEL}

In 1980, the Asian Studies Association published a comprehensive report on Asian Studies in Australia, officially known as "Asia in Australian Education" but unofficially referred to as the "FitzGerald Report" after the Chairman of the Report's Committee, Stephen FitzGerald. This wa the first and perhaps the most important report of its kind. It was in three volumes. The first volume consisted of 99 pages with 75 detailed resolutions/recommendations, many of them made up of several parts; the second, shorter volume provided a survey of Asian Studies in the country; while the third merely summarized the Report's resolutions. The Report called for the development of Asian Studies in schools, leading to more advanced study at university level. In particular, it recommended the teaching of "second-tier" languages - in the case of Southeast Asia, Thai, Vietnamese and Tagalog — at a tertiary institution.

This Report did not attempt to promote an area-studies approach in Australia. It pressed for the teaching of languages as essential to the study of Asia and then remarked on the practice, already developed in several Australian universities, of combining a discipline with knowledge of a country and its language. The Report thus called for "Asian content in discipline-based courses" (Resolution 11, in particular).

A key element in the development of Southeast Asian Studies in Australia was the existence in Canberra of the National Library of Australia. The Library had a long-standing policy acquiring books on and from the Asia-Pacific region and continues to maintain this policy to the present. The Library collects language and other research materials on (1) Indonesia (2) Thailand, (3) Vietnam, (4) Cambodia and (5) Burma/Myanmar and has a separate "Regional Asia" collection devoted to Malaysia, Singapore and the Philippines. The ANU Menzies Library, located directly opposite the Research School of Pacific and Asian Studies, has the second largest collection of books on Asia, making Canberra a focus for research on Asia.

Another innovation that began in the early 1980s at the ANU had a far-reaching effect on the way that Southeast Asian Studies was publicly perceived. On the 3rd of November 1983, the first Indonesia Update was held. The idea behind this and all subsequent "Updates" was to provide a public presentation of current developments in a particular country along with lectures on a specific topic in relation to that country. Indonesian Updates have been held each year in Canberra (and in recent years in Jakarta as well) since 1983. Other scholars have emulated this practice so that most every year there are Updates on the various countries in Southeast Asia, particularly Thailand, Vietnam, the Philippines and Myanmar

These Updates are open to the public and are well attended. The annual Indonesia Update is now held over two days and generally attracts 400 or more attendees - many, in Canberra, from government departments. Each year there is a lecture devoted to recent political developments and another devoted to economic developments, plus various presentations on the chosen topic. The goal is to increase public awareness but also to promote a more general understanding of academic research on these countries.

\section{GRADUATES IN SOUTHEAST ASIAN STUDIES IN THE 1980s AND THE 1990s}

Whereas a majority of Australians in the 1970s went overseas for their Ph.D. training and only a minority managed to do their Ph.D.s in Australia, things changed dramatically in the 1980s. Southeast Asian Studies in Australia, particularly the study of Indonesia and to a lesser extent, Thailand, expanded in the 1980s as a whole new generation of students did their doctoral work in Australia and then took up positions in various universities throughout the country.

Among Anthony Johns' students was Helen M. Creese whose dissertation in 1981 was on an Old Javanese kakawin, the Subhadrāwiwāha; she followed this with a study of an eighteenth-century Balinese text, Parthayana (1998) and an even more fascinating study of women of the Indic court world of Java and Bali (2004). Peter Riddell was another of Johns' students whose Ph.D. in 1984 on 'Abd Al-Ra'üf Al-Singili was eventually published in 1990. This work reflected Johns' ever increasing interest in Islam in Southeast Asia. Creese moved to teach in Queensland and Riddell to Brunel in London. Yet another graduate was Tim E. Behrend who submitted his doctoral dissertation on the various manuscripts of the Javanese poem, the Serat Jatiswara, in 1987. This study was published in Indonesian translation in 1995. Behrend was involved with Alan Feinstein in the microfilming of Javanese manuscripts particularly from the Museum Sonobudoyo in Yogyakarta. 
As retirements occurred in the Department, George Quinn was recruited research on Java, especially his studylarly in Javanese. His teaching and his considerably to the programme.

The Department of Political

of distinguished graduates: And and Social Change produced a number business-government relations in Indrew MacIntyre who wrote his Ph.D. on political intellectual and activist Soe political opposition in Indonesist, Soe Hok-Gie and Ed Aspinall on the and Aspinall returned tinued their research and a positions at the ANU where they contheses - MacIntyre: Business and Politich published books based on their Opposing Suharto: Compromise, Resistance in Indonesia (1991) and Aspinall. (2005). The book Compromise, Resistance and Regime Change in Indonesia aned Maxwell's thesis was published in Indonesian Indonesian film on for a widely acclaimed of Soe Hok-Gie.

In History, under the supervision of David Marr, Nola Cooke wrote in 1992 . Cochinching. Sa Na completed her thesis which was published as Nguŷen (1998). Cooke and Vietnam in the Seventeenth and Eighteenth Centuries of Chinese commerce in editing a valuable history supervised by Aurr and Wijeyewardene was Philip Taylor who was one of Taylor pustralians to carry out extended fieldwork in southern Vietnam. his first book, Fragments of the Present (2001), based on 2007). Li and Taylor subsequently published extensively on Vietnam (2004, Jane Drakard, kingdom in 1993 , he history of a Sumatran Kingdom of Words, on her thesis appeared in 1999.

In Anthropology, there were a significant number of new graduates urban kampong in urban kampong in Yogyakarta; in 1983, E. Douglas Lewis submitted his on a community in central east Flores; in 1984, Kathryn Robinson on a mining development in Sulawesi. Thereafter, in 1989, Andrew McWilliam completed his thesis on West Timor, Greg Acciaioli his thesis on a Bugis settlement in central Sulawesi and Lynette Parker her thesis on a Balinese village. Finally in 1990, Christine Helliwell submitted her thesis on a community in Borneo.
Guinness and Helliwell were appointed to teach in the Faculties at the ANU. Robinson, after a time at Newcastle and McWilliam, after a period of Aboriginal research, returned to Anthropology in the Research School. Lewis began in Western Australia but was then appointed to teach anthropology at Melbourne University. Acciaioli moved to teach anthropology at the University of Western Australia where he joined another of Fox's former students, John Gordon who received his Ph.D. from Harvard, while Lyn Parker took up a position in Asian Studies at the University. Penelope Graham who finished her thesis on eastern Flores in 1991 after having completed an MA thesis at the ANU on the Iban of Borneo (1987) moved to Monash to teach anthropology.

All of these graduates produced important publications based on their fieldwork. Guinness published his book, Harmony and Hierarchy, as an Asian Studies monograph in 1986; Robinson published her book, Stepchildren of Progress, also in 1986; Graham, her book, Iban Shamanism in 1987; Lewis his book, People of the Source, in 1988. Helliwell's book, Never Stand Alone appeared in 2001; McWilliam's, Paths of Origin, Gates of Life in 2003.

A later group of Fox's students also went on to teach in Australia: Minako Sakai who began the Indonesian language programme at the Australian Defense Force Academy (ADFA), attached to the University of New South Wales, Thomas Reuter who taught at Monash was awarded a Future Fellowship at Melbourne University while Phil Winn is currently at the ANU. Sakai's research was on Sumatra, Reuter's on Bali and Winn's on Banda Island in the Moluccas. Reuter published two volumes of ethnography on the Bali Aga: Custodians of the Sacred Mountains (2002a) and The House of our Ancestors (2002b).

In all, Fox supervised fifty-five doctoral dissertations in Anthropology at the ANU. Twenty of these Ph.D. theses were written by Indonesians. This number of Indonesian students points to another development that gained momentum in the 1980 s and increased rapidly in the 1990s. A large number of students, from Indonesia but also from Thailand and Vietnam, began coming to the ANU and other Australian universities for advanced training. On their return, these students contributed to the development of a network of cooperation throughout the region.

Fox was also responsible for the creation of an Ethnographic Film Unit attached to the Research School. With the support, collaboration and impetus provided by two outstanding film-makers, Timothy and Patsy Asch, he and some of his students (Bubandt, Lewis, Suwandi and Vischer) made a series of films on eastern Indonesia and Java. 
At the ANU, Bellwood had a seminal influence on Southeast Asian archaeology. He trained a host of Southeast Asian students from Brunei, Malaysia, Thailand, Laos and particularly Indonesia, most of whom did their own important excavations under his guidance. In cooperation with his students and other local colleagues, he also carried out a succession of investigations on regional prehistory: in the 1970s, in North Sulawesi including Talaud and Sangihe, in the 1980s, in Sabah, in the 1990s, in the northern Moluccas and thereafter on the Batanes Islands of northern Philippines. On all of these sites, he published valuable papers and monographs and at the same time, he has written the key volumes that have synthesized current knowledge (1997) and argued for the importance of the spread of farming cultures in the region and into the Pacific. He was a key participant in the Comparative Austronesian Project initiated by Fox in the 1990s and served as one of the editors of The Austronesians (1995).

Among Bellwood's Australian students, David Bulbeck, who finished his thesis in 1992 and was a participant in the Comparative Austronesian Project, carried out research on the historical archaeology of Gowa and Tallok in South Sulawesi. He and Ian Caldwell, an ANU student of Campbell Macknight, and now at Leeds University, have gone to work together on the history and archaeology of Luwu and the Cenrana valley of Sulawesi (2000).

In 1995, another ANU graduate based at the University of New England, Mike Morwood, whose Ph.D. thesis was on the prehistory of central western Queensland, joined a major excavation project in central Flores that continued for almost a decade and resulted in the discovery of a possible new species, homo floresiensis, popularly known as the "hobbit". These skeletal remains have been the subject of continuing controversy since their discovery (Morwood and Oosterzee 2007).

In the same year, 1995, two archaeologists from the ANU, Sue O'Connor and Matthew Spriggs together with Peter Veth from James Cook University, began excavations on the Aru Islands, hoping to find evidence of early migration that may have carried via New Guinea into Australia. O'Connor and Veth edited a substantial interdisciplinary volume, East of Wallace's Line, in 2000 and all three collaborators published the results of the Aru research in 2005.

With the end of the Indonesian occupation of East Timor, these same archaeologists have turned their attention to Timor following on from the original work of Glover in the 1960s. Their excavations have uncovered evidence of human settlement dating back 35,000 years.

\section{THE BLOSSOMING OF SOUTHEAST ASIAN STUDIES AT UNIVERSITIES AROUND AUSTRALIA}

Monash University sought new talent from overseas. The University appointed the anthropologist Joel Kahn and, a few years later, the historian Merle Ricklefs to professorships. Both scholars were highly productive. After some years at Monash, Kahn moved to La Trobe University and Ricklefs to the ANU where he became the Director of the Research School of Pacific and Asian Studies. From the ANU, he moved, for a time, to be Director of the Melbourne Institute of Asian Languages and Societies.

Monash continued to produce significant graduates. Two such graduates, Greg Barton, a student of Herb Feith, and, later, Greg Fealy, a student of Merle Ricklefs both produced important theses on Indonesian Islam. Barton wrote his thesis on several leading Islamic thinkers, including Djohan Effendi who himself came to Monash for a Ph.D. Fealy wrote his thesis on the history of Nahdlatul Ulama, Indonesia's largest Muslim organization. Together the two edited a volume on Nahdlatul Ulama (1996). Barton went on to write a biography of Abdurrahman Wahid (2002) and was eventually appointed Herb Feith Professor for the Study of Indonesia at Monash. Fealy whose thesis has been published in Indonesian (2003) took up a position whose thesis has Social Change, the Department founded by Jamie Mackie. At the ANU, he has collaborated with various colleagues on a variety of publications on Islam: Bubalo (2005) and Hooker (2006).

Melbourne appointed the well-known Indonesian researcher and commentator, Arief Budiman, to a professorship in its Institute of Asian Languages and Societies. In 1990, Timothy Lindsey who had done his doctorate in Indonesian studies took up a position in the Asian Law Centre, where he became Director and was exceptionally influential in promoting the study of both Islamic and Indonesian law as well as law reform. In addition to a major work, Indonesia: Law and Society (1st ed., 1999), he has edited a book with his Melbourne colleague, Howard Dick, on corruption in Asia, particularly Indonesia and Vietnam (2002).

Sydney University where Bali had been a focus of study under Worsley Sydney two distinguished Bali researchers: Adrian Vickers who completed his 列 1986 and Linda Connor who did extensive thesis on a Balinese Malat Ph.D. Vickers published a version of his thesis in 2005 fieldwork in Bali for her Ph.D. Vickers published a version of $)$ Connor worked after a variety of other publications on Bali $(1989,1996)$; Connor worked with Patsy and Tim Asch to produce a monograph on the films that (Newcastle made together on Balinese trance. After teaching careers esewh-Wollongong and Wollongong and involvement in the joint Newcastle-Wollongong 
Richard Robison who did his at Sydney were among the first scholars of the Sydney Department's earlier to teach at Sydney University. One submitted his thesis on Mats Monash and Flinders Universities, literature in 1974 and then taught at both of Indonesian Studies in 1996 , returned to Sydney to head the Department

on Indonesia ing the Javanese performing arts. She table research in Yogyakarta, study(Lindsay 1979; 2nd translation in 1991 and translation in 1991 and then translated essays by the distinguished editor also involved in a project manuscripts of hroject supported by the Ford Foundation to microfilm descriptive catalogue Kraton Yogyakarta. These microfilms with a preliminary final catalogue was wube made available in 1987 (Lindsay et al. 1987); a al. 1994). The anthropologin Indonesian translation in 1994 (Lindsay et research in Indon alexander also carried out valuable her husband, Paul Alerander whosearch was on Javanese rural trade (1987); Lanka, took volume, Creating indorest in Indonesia and worked with her. He edited the (1989). Jennifer Alexander then went on to do further research in Sarawak, particularly among the historian, Michael Laffan did seminal research on Islam during the colonial period (Laffan 2003); he taught for a period at the ANU, before taking up a fellowship in Leiden and eventually a professorship at Princeton.

The Asia Centre at Flinders University was only established in 2000. Prior to its establishment, Southeast Asian research at the University was directed primarily to Indonesia through a programme begun by Anton Lucas who graduated in history at the ANU in 1980; his study of revolutionary north coast Java appeared as a Southeast Asia monograph in 1991.

At different stages in its development, the Flinders programme included notable scholars such as Colin Brown, Jim Schiller and his wife Barbara Martin Schiller. Now the Asia Centre is headed by Elizabeth Morrell, a graduate of Flinders who has done research on the Toraja of Sulawesi (2000) and Malaysias Michael Barr who has done research on Singapore (2000) and Malaysia, and Anthony Langlois whose focus is on human in Southeast Asia (2001).

The universities in Western Australia began to develop their Southeast Asia expertise a generation or more after universities on the east coast but they were soon able to rival these universities with their array of talented research scholars. James Warren who did his Ph.D. at the ANU and to take up positions at Murdoch University; they were followed later by Krishna Sen and David Hill whose research examined the role of cinema (Sen 1994), the media and the internet (Hill and Sen 2005) in Indonesia. Together with graduates of Murdoch, Kevin Hewison whose research was on capital formation and state politics in Thailand (1989), Carol Warren whose initial research was on Bali (1993) and Garry Rodan whose research on the political economy of authoritarian regimes in Southeast Asia had a focus on Singapore (1989), they became part of Murdoch's Asia Research Centre that was created in 1991 to cover the whole of the Asia region. Ian Chalmers, an ANU graduate whose research is on government-business relations in Indonesia and who teaches at Curtin University of Technology, is also a member of Murdoch's Asia Research Centre. He has edited a book on the politics of economic development with Vedi Hadiz (1997), a graduate of Murdoch, who has now returned to the university as a Future Fellow and will continue Murdoch's tradition of research on political economy.

As research on Southeast Asia continued to develop at the University Western Australia, scholars were recruited from a wide number of Australian universities: Greg Acciaioli and Lyn Parker, graduates from the ANU, Michael Pinches and David Bourchier who graduated from Monash, Lenore Lyons from Wollongong, Stephen Dobbs from Murdoch and most recently, Krishna Sen who has become Professor and Dean of the Faculty of Arts, Humanities and Social Sciences.

Charles Darwin University in Darwin, formerly the Northern Territory University (NTU), offers itself as "Australia’s Gateway to Asia". During the time that it was still the NTU, Paul Webb established a small but notable Centre for Southeast Asian Studies at the University that had its focus primarily on eastern Indonesia, which he had made his special interest (1986). This Centre did not, however, survive various internal reorganizations of the university and subsequent efforts at teaching Indonesian were intermittent. Despite these setbacks, the University still maintains a small group of scholars working on Southeast Asia: Dennis Shoesmith whose research is on the comparative politics of the region, David Mearns whose research has been on both Malaysia and on Maluku, Natasha Stacey whose research is on the maritime populations of eastern Indonesia and Steven Farram whose research is on Timor, both East and West. In recent years, more efforts have been directed to Timor-Leste than to Indonesia.

James Cook University of Northern Queensland has been more successful in maintaining its Centre for South-East Asian Studies. This has been due 
in large part to the work of B.B. Hering who has also maintained the biannual journal, Kabar Seberang Sulating Maphilindo which is a multidisciplinary journal that publishes on Southeast Asia and adjacent areas of the western Pacific. Hering's Ph.D. research at the University of Queensland focused on a key nationalist figure in Indonesia, Mohammed Thamrin (1996). He, too, collaborated with Chris Penders, in this case, in editing the memoires of an Indonesian diplomat, Ganis Harsono (1977). With the close cooperation of Pramoedya Ananta Toer, Hering devoted a special issue of Kabar Seberang to a commemorative volume to honour the writer on his 70th birthday (1995).

A successful programme of Indonesian studies was established in 1999 at the Australian Defence Force Academy in Canberra which forms part of the University of New South Wales. The programme, which has been headed by Minako Sakai with the support of Paul Tickell, provides a full major in Indonesian studies and has become one of the larger Indonesian language programmes in Australia.

Elsewhere at other Australian universities, even where there have been no major programmes in Asian or Southeast Asian Studies, there have been notable research scholars who have contributed to the field: Amarjit Kaur at the University of New England, Carl Trocki at Queensland University of Technology, David Reeve at the University of New South Wales, Barbara Leigh at the University of Technology Sydney, Steven Drakeley at the University of Western Sydney, Alberto Gomes at La Trobe University and Pamela Allen at the University of Tasmania. Margaret Kartomi is another scholar who as Professor at Monash University, has charted her own distinct but highly productive research programme in the ethnomusicology of Southeast Asia, in particular Indonesia.

One of the innovations of the early 1990s was the creation of "The Australian Consortium for 'In-Country' Indonesian Studies (ACICIS)" which was established in 1994 to develop and coordinate a programme for students interested in the study of Indonesian at university level in Indonesia. It was especially useful to draw together students from universities across Australia.

ACICIS has developed to include nineteen Australian universities (plus The School of Oriental and African Studies, University of London and Leiden University) which are now partnered with six different universities and institutes in Indonesia. Over a period of more than fifteen years, the programme has channelled hundreds of students to Indonesia for accredited in-country academic training. Currently ACICIS is coordinated by a secretariat based at Murdoch University.

\section{CONTRIBUTIONS TO SOUTHEAST ASIAN STUDIES FROM BEYOND THE ACADEMY}

Any survey of the development of Southeast Asian studies in Australia cannot ignore the considerable contributions to scholarship by independent researchers who, for the most part, did their work outside the confines of universities. Such contributions would include Bruce Grant's Indonesia (1964), Peter Polomka's Indonesia since Sukarno (1971), Hamish McDonald's Suharto's Indonesia (1980), David Jenkins's Suharto and His Generals (1984) and Max Lane's Unfinished Nation: Indonesia before and after Subarto (2008). Among this group would also be Graeme Dobell who has consistently reported on Southeast Asia for the Australian Broadcasting Corporation (2000) and Patrick Walters who has done the same in The Australian. Those who pursued diplomatic and government careers would include Jeff Forrester and Ken Ward (1974). Also included within this group would be both Max Lane and Harry Aveling whose translations from the Indonesian, particularly of Pramoedya Ananta Toer's work and whose critical commentary have been notable. Milton Osborne needs also to be added to this group. Osborne, whose work includes Southeast Asia: An Introductory History (1979a), was a member of the wave of Australians to return from Cornell with their Ph.D.s. His thesis was submitted in 1978. Although he has spent time in academia, like the others in this group, he has spent more time in a variety of other occupations but he has published prolifically. Harry Aveling is another scholar who is difficult to categorize. He has held numerous visiting and adjunct positions in Australia, the United States and Southeast Asia. As a wandering scholar, he has been enormously productive in his translations and commentaries on Indonesian literature.

Academic research on Southeast Asia has also been supported through cooperation with various museums in Australia. In the 1980s, the Australian National Gallery under its Director, James Mollison, established a four member committee consisting of Anthony Forge, James J. Fox, Robyn and John Maxwell to advise on the creation of a collection of Southeast Asian textiles. This collection has now grown to be the largest and probably the most distinguished collection of its kind in the world and has opened the way to the study of trade patterns and cultural influences throughout the region. Robyn Maxwell, who for many years held positions at the ANU and the National Gallery, has published two major volumes $(1990,2003)$ on the collection.

In 1980, Don Hein at the Art Gallery of South Australia formed the Thai Ceramics Dating Project, which became the Thai Ceramics Archaeological 
Project when the Gallery began cooperating with the University of Adelaide. In 1984, the two institutions formed the Research Centre for Southeast Asian Ceramics. Initially the Centre investigated fifty or more kilns in central Thailand, collecting and cataloguing thousands of ceramic finds (Hein and Sangkhanukit 1984); eventually the Centre extended its research elsewhere in Thailand and into Laos (Hein et al. 1989).

At about this same time, in 1979-80, the Western Australian Maritime Museum began the development of maritime archaeology in Southeast Asia, forming a joint Thai-Australia team to excavate the Ko Kradat ship wreck in the Gulf of Thailand. The Museum went on to investigate other shipwrecks near Pattaya and Bangkok in the 1980s and since that time has continued research on pre-colonial ships and ship-building in the Indian Ocean and South China Sea, including the Philippine coast (Green and Harper 1983; Green 1990; Clark et al. 1993).

\section{THE DEVELOPMENT OF THE STUDY OF "OTHER" COUNTRIES IN SOUTHEAST ASIA}

It is instructive to contrast the concerted efforts that went into establishing Indonesian studies in Australia with the way in which studies on other countries in Southeast Asia - such as Thailand, Vietnam, the Philippines, Cambodia and Myanmar developed. From the beginning, it was deemed essential that Indonesian/Malay language teaching form the basis for further study. In the case of Thailand, research in various disciplines preceded the beginnings of proper language teaching. In the case of Vietnam, there was a lag in the development of language training compared to other research efforts and in the case of the Philippines, despite some short-term efforts, no language programme ever became established. For Myanmar, only an occasional summer course in Burmese has ever been offered.

At the ANU, for example, early on, Silcock in economics provided some research coverage of Thailand. The anthropologist, G. Wijeyewardene turned his interests to Thai from an early interest in Ceylon; the political scientist, Ron May and the geographer, Ted Chapman conducted research in Thailand before the Thai language began to be officially taught. Similarly the anthropologist/historian, Baas Terwiel, whose doctoral fieldwork for a European university involved spending a year in a Thai monastery, began teaching in the Faculties as did the economist, Peter Warr, before the initiation of Thai language study. Peter Jackson did his ANU Ph.D. dissertation on Buddhist philosophy and only afterwards began his study of Thai with Tony Diller. Nicholas Tapp, whose primary interests were on the ethnic minorities of upland Thai region, replaced Wijeyewardene on his retirement to continue the long-running Thai-Yunnan Project. The same could be said for Sydney University where there was no language programme for Thai. Geddes and others at Sydney were able to shift interests to Thailand despite a lack of Thai language training in Sydney and the Cornell-trained historian, Craig Reynolds successfully taught on Thailand at Sydney for many years before moving to the ANU. Only in 1989 was he National Thai Studies Association of Australia established to provide a national forum to promote the development of Thai language and Thai studies teaching in Australia.

At the ANU, the combination of interests provided through the work of Diller, Warr, Reynolds, Jackson and, later, by one of Wijeyewardene's students, Andrew Walker produced a varied but substantial programme of Thai studies.

Much the same can be seen in the development of Vietnam studies: ro was doing fundamental research on Vietnam decades before the establishment of Vietnamese at the ANU. Similarly, although Tagalog was never established as a regular language programme, a number of scholars managed to pursue research on the Philippines. At the ANU, this group included at one time Ron May, Peter Warr, Hal Hill, Rey Ileto and later Ben Kerkvliet who was appointed as Professor of Political and Social Change replace Jamie Mackie. The tradition has continued with the appointment of Paul Hutchcroft after the retirement of Ben Kerkvliet. Hutchcroft who did his Ph.D. at Yale University has published extensively on Philippine politics, most notably on the politics of banking (1998). The Research Sciported a number of research fellows, such as Brian Fegan, who did his research on the Philippines.

Martin Stuart-Fox at the University of Queensland stands out, among Ascholars in Australia, in his remarkable commitment to Southeast Asian scholars in Australia he has published over a dozen books and the study of Laos, on which he has published monographs from the early 1980 s to the present (1982, 2010$)$

\section{CONCLUSION}

Robert Cribb has written of "circles of esteem" that define and enhance relationships among groups of scholars $(2005 \mathrm{~b})$. Members of these clusters respect each others' research and often regard themselves as engaging in a similar effort or as Cribb describes it, "working a related part of the same story, manufacturing pieces, perhaps, for the same jigsaw puzzle" (2005 b, p. 292). Certainly clusters of this sort, often initiated by a particular teacher, 
are recognizable in the generations of scholars in Australia. Early on in the development of Southeast Asian Studies, Anthony Johns' students were one such group - or perhaps two groups, those interested in philology and those interested in Islam; Heinz Arndt's group of economists formed another clear cluster. There were common features among the many graduates of Monash but they were also a diverse group with separate interests. Peter Worsley at Sydney stimulated a number of students to do research on Bali as did James Fox at the ANU for the ethnography of eastern Indonesia, though a majority of his Indonesian students did research on Java and particularly on Islam in Java. (Seven of these studies have been published by the ANU E Press in a series entitled Islam in Southeast Asia.)

Clearly, too, the group of political economists - Hewison, Rodan, Hadiz, all inspired by Robison, along with a number of other similarly oriented colleagues - can be recognized as an important circle of esteem. However, possibly the largest of these circles of esteem is that group of women scholars who have contributed publications to the Women in Asia series, created by the Asian Studies Association of Australia. Their work on Southeast Asia comprises over a dozen publications including books by Linda Bennett (2005), Michele Ford and Lyn Parker (2008), Sharyn Graham (2010), Anne-Marie Hilsdon (1995), Elizabeth Martyn (2005), Nina Nurmila (2009), Kathryn Robinson (2009b), Kate O'Shaughnessy (2009), Maila Stivens (1996), Norma Sullivan (1994) and Andrea Whittaker $(2000,2004)$. Were one to add to this, the work of Susan Blackburn (2004), one of the editors of the series, this would represent a formidable circle of esteem within Southeast Asian Studies.

Yet despite the existence of these clusters that extend research throughout Southeast Asia, Australia has never committed itself to the study of Southeast Asia as an "area studies programme". Australia is, however, committed to the study of Asia but it does this by promoting Asian content in recognized disciplines: Anthropology, Demography, Political Science, History, Economics, Law, and the Arts. This is now an accepted aspect of Australian university teaching. A consequence of this is that language programmes for the major languages of Asia have found a place at some Australian universities but less prominent Southeast Asian languages have failed to gain an appropriate position.

In 1964, Anthony Johns entitled his inaugural lecture as Foundation Professor of Indonesian studies at the ANU as "An Open Horizon". He asserted that "orientalism in the old sense" was dead but "phoenixlike, out of its ashes, something new is arising [that] takes on new life as it informs and sustains work in the fields of literature, linguistics,
A history, an to bed on a envisaged was a new wave of sthe region deep knowledge and a thorough command of a within particular disciplines, whose understanding informed investigations, within particular specialized of the full context of particular research. At the core of the country, a studies was a commitment to specific locations - an area, a country, region - and a discipline that was grounded in a focused understan. To a considerable extent, this vision has indeed characterized a succession of several generations of scholarship in Australia since the mid-1960s and allowed Southeast Asian Studies to flourish.

These studies have indeed opened a wide horizon. By their very success, have lost much of their original specialist appeal. In Australia, eneral knowledge of Southeast Asia has become more widespread as specific knowledge of particular countries within the region has developed. In the 列 1900s, Australians visiting countries like Indonesia, Malaysia, Singapore 列 or Thailand number in the hundreds of thousands with gained in-country has of Australian residents in the region. Knowledge gain as have the decades added immeasurably to the understanding of he regionts of education and training offered by Australian acaden and expertise on both in Australia and from Southeast Asia

Southeast Asia has thus diffused widely.

In attracting new students, Southeast Asian Stu of China, in the past compete with other studies, particularly the study of Che programmes that two decades. This is particularly evident in the langed study. In Australian originally served as the foundation for specialized study of Chinese, universities, at present, language programmes for the sad any of the Japanese and Korean now attract more students than do. All of these programmes for the study of lang

programmes show a steady decline.

A report, dated the 10th of April 2008, commissioned by the Asian Studies Association of Australia and prepared by Anne McLaren on Asian language enrolments in Australian Institutes of Higher Education in noted strong growth (31 per cent) in enrolments in Chinese, reasonab growth ( 15 per cent) in Korean, and limited growth (1.5 per cen) in Japanese but a marked decline ( 24 per cent) in Indonesian and precipitous declines (77-79 per cent) for the already minor teaching programmes in Thai and Vietnamese. 
In 2006-07, there were 32 institutions in Australia teaching Japanese, 26 institutions teaching Chinese and 20 institutions teaching Indonesian but between 2001 and 2004, four universities had dropped their Indonesian programmes. Three universities had dropped their Thai language programmes, leaving only two universities teaching Thai and only two universities teaching Vietnamese. Only the ANU continued to teach all three languages - Indonesian, Thai and Vietnamese.

At the same time, many - possibly a majority — of those whose work is cited in this chapter have retired, are about to retire, or are preparing to retire within the decade. There will be considerable generational change in Southeast Asian Studies in Australia in the near future. A new generation - many of whom have not been cited in this historical review - is taking over, but they do so in the context of a globalized world of internet communication and rapid dissemination of knowledge.

\section{Notes}

I should properly indicate my own personal background (and bias) in offering this genealogy. I have spent the whole of my career in Australia at the Australian National University (ANU) and as a consequence, am better acquainted with its development than that of any other university in the country. Since its foundation, the ANU has had a prominent role in the study of the AsiaPacific region. It is difficult therefore not to give emphasis to its importance.

This chapter has gone through various drafts which I have shown to colleagues to ask for comment and advice. I would like to thank Robert Cribb, Jamie Mackie and Campbell Macknight in particular for their considerable assistance. I have also relied on a number of articles written by others on the development of Southeast Asian Studies in Australia. All of these articles are included in the bibliography.

It is important to appreciate the political climate of this period and the significance given by key government figures to orienting Australia to the AsiaPacific region. A book that provides a good background to these efforts is Daniel Oakman's Facing Asia: A History of the Colombo Plan (2004).

Bahasa Indonesia, Langkah Baru, A New Approach was first produced in 1975 within the Faculty of Asian Studies in collaboration with Robyn Stokes. It was subsequently published and republished by the Australian National University Press as it went through successive revisions and expansions.

$4 \quad$ This was first published as a government report but was later reprinted in the London University Anthropology series.

Like Freeman, the report on his fieldwork among the Land Dayak was published as a government document.
In the early 1970s, Geddes' association with the Tribal Research Center (TRC) in Chiang Mai in Thailand was the subject of criticism and controversy because of accusations that the TRC was involved in counter-insurgency. See Robinson (2004)

The establishment of extensive cooperative links between individual scholars in Australia and former students and colleagues in Southeast Asia was perhaps in lishing its Asian studies programmes. Although some of these connections are lishing its Asian studies programmes. Although some of these connections are would require another long paper.

\section{References}

Asia in Australian Education. Asian Studies Association of Australia, 1980. Bulletin of Indonesian Economic Studies. Basingstoke: Taylor \& Francis, 1965-the present.

Kabar Seberang Sulating Maphilindo. Centre for Southeast Asian Studies, James Cook University of North Queensland, Townville.

Abeyasekere, Susan. One Hand Clapping: Indonesian Nationalists and the Dutch, 1939-1942. Clayton: Centre for Southeast Asian Studies, 1976.

Jakarta: A History. Singapore: Oxford University Press, 1987.

Acciaioli, Gregory, C. van Dijk, and Roger Tol, eds. Authority and Enterprise among the Peoples of South Sulawesi. Leiden, KITLV Press, 2000.

Alexander, Jennifer. Trade, Traders and Trading in Rural Java. Singapore: Oxford University Press, 1987.

Alexander, Paul, ed. Creating Indonesian Cultures. Sydney: Oceania Publication, 1989.

Allen, Pamela. Membaca dan Membaca lagi: Reinterpretasi Fiksi Indonesia, 1980-1995. Magelang: Indonesia Tera, 2004.

Andaya, Barbara W. Perak, the Abode of Grace: A Study of an Eighteenth-Century Malay State. Kuala Lumpur: Oxford University Press, 1979

Andaya, Leonard Y. The Kingdom of Johor, 1641-1728. Kuala Lumpur: Oxford University Press, 1975.

Arndt, Heinz W. The Indonesian Economy. Collected Papers of H.W. Arndt. Singapore: Chopmen, 1984.

A Course through Life: Memoirs of an Australian Economist. Canberra: The Australian National University, 1985.

Arndt, Heinz W. and R. M. Sundrum. Transmigration: Land Settlement or Regional Development? Canberra: Research School of Pacific Studies, 1977.

Aspinall, Edward. Opposing Suharto: Compromise, Resistance and Regime Change in Indonesia. Stanford, CA: Stanford University Press, 2005.

Aveling, Harry, ed. and trans. Contemporary Indonesian Poetry: Poems in Bahasa Indonesia and English. St. Lucia: University of Queensland Press, 1975. 
1880-1941: The Social History of a European Butcher, John. The British in Malaya, 1880- Kuala Lumpur: Oxford University Community in Colonial South-East Asia. Kuala Lurine Fisheries of Southeast
Press, 1979.

, ed. The Development of Indonesian Society: From the Coming

Present Day. St. Lucia: University of Queensland Press, RIMA 43, no. 1 (2009):

- "Literature and the Australian Study of Indones

35-50.

Barlow, Colin. The Natural Rubber Industry: Its University Press, 1978.

Economy in Malaysia. Kuala Lumpur: Oxford Unive

Barr, Michael D. Lee Kuan Yew: The Belie

Georgetown University Press, 2000.

Barton, Greg. Abdurrahman Wahid: Muslim Democrat, Indonesian 2002.

from Inside. Honolulu: University of Hawai in Australia". Korte Mededelingen,

Bastin, John. "Indonesian and Malayan Studies in Australia" 2 (1957): 201-4.

Bijdragen tot de Taal-, Land-en Volkenkunde 11 Perubahan di dalam Puisi Jawa,

Behrend, Timothy E. Surat Jatiswara:

1600-1930. Jakarta: INIS, 1995.

Behrend, Timothy E. and Alan H. Feinstein.

Yogyakarta. [Microform 1-162 reels] n.d.

Bellwood, Peter S. Prehistory of the Indo-Malaysian Archipelago. Sydney: Acai, 1997.

Press, 1985; Revised edition, Honolulu: University of Pubs, 2005.

Pubs, 2005. The Austronesians: Historical ellwood, Peter, James J. Fox, Canberra: ANU, 1995. ANU E Press Publication, \& Comparative Perspectives. Canberra. AN

available at <http://epress.anu.edu.au>.

Bennett, Linda Rae. Women, Islam and Modernity. Single Womentedge, 2005.

Reproductive Health in Contemporary Indonesia. London: Routedge: Cambridge

Blackburn, Susan. Women and

University Press, 2004.

Booth, Anne. Agricultural Development in Indonesia. Sydney: Allen \& Unwin, 1988.

Anne and Peter McCawley, eds. The Indonesian Economy during the Suharto Era. Kuala Lumpur: Oxford University Press, 1981.

Era. Kuala Lumpur. Ox Hadiz, eds. Indonesian Politics and Society: A Reader. Bourchier, David and Vedi 2003.

New York: Routledge, The Hikayat Muhammad Hanafiyyah: A Medieval Muslim-Malay Romance. The Hague: Nijhoff, 1975.

the Australian Contribution to the ulbeck, David. "A Historical in Southeast Asia". Australian Archaeology 50 (2000):

Bulbeck, David and Ian Caldwell. Land of Iron: The Historical Archaeology of Luwu and the Cenrana Valley. Hull: Centre for South-East Asian Studies, University of Hull, 2000

Asia 1850-2000. Singapore: Institute of Southeast Asian Studies, 2004. Asia, 1850-2000. San and Vedi R. Hadiz, eds. The Politics of Economic

Indonesia: Contending Perspectives. London: Routledge,

Chandler, David. The Land and People of Cambodia. Philadelph 1972.

A History of Cambodia. Boulder: Westview Press, 1983. Sydney: Allen 8 - Facing the

Unwin, 1996.
Clark, P., J. Green, T. Vosmer, and R. Santiago. "The Butuan Two Boat Known as The International a Balangay in the National Museum, 143-59.

Journal of Nautical Archaeology 22 (19) Hero Tapakan, Balinese Healer Connor, Linda, Patsy Asch, and Tim Asch. Jero Tapakan, Balinese Hesters, 1986. Ethnographic Film Monograph. Cambridge: Cambridge University Prese in the

Cooke, Nola and Li Ta Na, eds. Water Frontier: Comment \& Littlefield. 2004.

Lower Mekong Region, 1750-1880. Lanham: Rowman \&eorge Allen \& Unwin,

Coppel, Cha 1983.

Studying Ethnic Chinese in Indonesia. Singapore: Singapore Society of Asia Studies, 2002

- ed. Violent Conflicts in Indonesia: Analysis, Representation and Resolution. London: Routledge, 2006

Helen M Parthayana: The Journeying of Partha: An Eighteen Century Balinese Kakawin. Leiden: KITLV Press, 1998. Women of the Kakawin World: Marriage and

of Java and Bali. London: M.E. Sharpe, 2004 . Cribb, Robert. Gangsters and Revolutionaries: The Jakarta Peoples Hawii Press, Indonesian Revolution, 1945-1949. Honolulu: Univen NIAS, 2005a. 1991.

Digital Atlas of Indonesian History. Copenhagen: NIAS, 2005lets: Dynamics "Circles of Esteem, Standard Works, and Euphoric Couplets. Dtudies 37, no. 2 - "Circles of Esteem, Standosian Studies". Critical Asian Studies 37, no. 2

(2005b): 289-304. Cribb, Robert and Colin Brown. Modern Indonesia: $A$ History since 1945. Longman, 1995.

Crouch, Harold A. The Army and Politics in Indonesia. Ithaca: Cornell University Press, 1978.

Malaysia's

Studies, 1982 
Government and Society in Malaysia. Ithaca: Cornell University Press 1996.

Dick, Howard W. The Indonesian Interisland Shipping Industry. Singapore: Institute of Southeast Asian Studies, 1986.

. Surabaya, City of Work: A Socioeconomic History, 1900-2000. Athens: Ohio University Press, 2002.

Dobbin, Christine. Islamic Revivalism in a Changing Peasant Economy: Central Sumatra 1784-1847. London: Curzon Press, 1983.

Dobell, Graeme. Australia Finds Home: The Choices and Chances of an Asia Pacific Journey. Sydney: ABC Books, 2000.

Drakard, Jane. A Kingdom of Words: Language and Power in Sumatra. New York: Oxford University Press, 1999.

Elson, Robert E. Javanese Peasants and the Colonial Sugar Industry. Singapore: University of Oxford Press, 1984.

Village Java under the Cultivation System. Sydney: Allen \& Unwin, 1994. - Suharto: A Political Biography. Cambridge: Cambridge University Press, 2001.

- The Idea of Indonesia: A History. Cambridge: Cambridge University Press, 2008.

Fealy, Greg. Ijtihad Politik Ulama: Sejarah Nahdlatul Ulama, 1952-1967. Yogkakarta: LKiS, 2003.

Fealy, Greg and Greg Barton, eds. Nahdlatul Ulama, Traditional Islam and Modernity in Indonesia. Clayton: Monash Asia Institute, Monash University, 1998.

Fealy, Greg and Anthony Bubalo. "Joining the Caravan? The Middle East, Islamism and Indonesia”. Lowy Institute Paper no. 5, Lowy Institute for International Policy. Sydney: Longueville Press, 2005.

Fealy, Greg and Virginia Hooker, eds. Voices of Islam in Southeast Asia: A Contemporary Source Book. Singapore: Institute of Southeast Asian Studies, 2006.

Feith, Herbert. Indonesian Politics 1949-1957: The Decline of the Representative Government. Ithaca: Cornell University, 1961.

. The Decline of Constitutional Democracy in Indonesia. Ithaca: Cornell University Press, 1962.

Fisk, E.K. Studies in the Rural Economy of South-East Asia. Singapore: Eastern Universities Press, 1964.

Fisk, E.K. and H. Osman-Rani, eds. The Political Economy of Malaysia. Cxford: Oxford University Press, 1982.

Fisk, E.K and Thomas H. Silcock, eds. The Political Economy of Independent Malaya: A Case Study in Development. Canberra: ANU Press, 1963.

Ford, Michele and Lyn Parker, eds. Women and Work in Indonesia. London: Routledge, 2008.

Foulcher, Keith. Pujangga Baru: Literature and Nationalism in Indonesia, 1933-1942. Bedford Park, S.A.: Flinders University Asian Studies Monographs, 1980.
Social Commitment in Literature and the Arts: The Indonesian "Institute of Peoples' Culture" 1950-1965. Clayton: Centre of Southeast Asian Studies, Monash University, 1986.

Fox, James J. Harvest of the Palm: Ecological Change in Eastern Indonesia. Cambridge, MA: Harvard University Press, 1977.

-, ed. The Flow of Life: Essays on Eastern Indonesia. Cambridge, MA: Harvard University Press, 1980.

- ed. To Speak in Pairs: Essays on the Ritual Languages of Eastern Indonesia. Cambridge: Cambridge University Press, 1988.

ed. Inside Austronesian Houses: Perspectives on Domestic Designs for Living. Canberra: Anthropology, Research School of Pacific Studies, 1993. ANU E Press Publication, available at <http://epress.anu.edu.au/>.

Fox, James J., R.G. Garnaut, P.T. McCawley, and J.A.C. Mackie, eds. Indonesia: Australian Perspectives. Canberra: Research School of Pacific Studies, The Australian National University, 1980. [includes Indonesia: The Making of a Culture; Indonesia: Dualism, Growth and Poverty; and, Indonesia: The Making of a Nation]

Fox, James, Timothy Asch, and Patsy Asch. The Water of Words: A Cultural Ecology of an Eastern Indonesian Island. $16 \mathrm{~mm}$ colour film. Watertown, MA: Documentary Educational Resources, 1983.

Freeman, Derek. Iban Agriculture. London: Her Majesty's Stationery Office, 1955. . Report on the Iban. London: University of London, The Athlone Press, 1970.

Garnaut, Ross. "Real Australians in Economics". In The Coombs: A House of Memories, edited by Brij V. Lal and Allison Ley. Canberra: Research School of Pacific and Asian Studies, The Australian National University, 2006.

Garnaut, Ross and Chris Manning. Irian Jaya: The Transformation of a Melanesian Economy. Canberra: Australian National University Press, 1974.

Geddes, W.H. Land Dayaks of Sarawak. London: H.M. Stationery for the Colonial Office, 1954.

. Nine Dayak Nights. Melbourne: Oxford University Press, 1957.

- Migrants of the Mountains: The Cultural Ecology of the Blue Miao (Hmong Njua) of Thailand. Oxford: Clarendon Press. 1976.

Glover, Ian. Archaeology in Eastern Timor, 1966-67. Terra Australis No. 11. Canberra: Department of Prehistory, Research School of Pacific Studies, The Australian National University, 1986.

Gomes, Alberto. Modernity and Malaysia: Settling the Menraq Forest Nomads. New York: Routledge, 2007.

Graham, Penelope. Iban Shamanism. Canberra: Research School of Pacific and Asian Studies, 1987.

Graham, Sharyn Leanne. Gender Diversity in Indonesia: Sexuality, Islam and Queer Selves. London: Routledge, 2010. 
Grant, Bruce. Indonesia. London: Melbourne University Press, 1964.

Green, J. "Maritime Archaeology in Southeast and East Asia". Antiquity 64 (1990): 347-63.

Green, J. and R. Harper. The Excavation of the Pattaya Wreck Site and Survey of Three Other Sites in Thailand. Fremantle: Australian Institute for Marine Archaeology, 1983.

Guinness, Patrick. Harmony and Hierarchy in a Javanese Kampung. Singapore: Oxford University Press, 1986.

Hadiz, Vedi. Workers and the State in New Order Indonesia. London: Routledge, 1997.

Harvey, Barbara. Permesta: Half a Rebellion. Ithaca: Cornell Modern Indonesia Project, 1977.

Hatley, Barbara. Javanese Performances on an Indonesian Stage: Contesting Culture, Embracing Change. Singapore: NUS Press, 2008.

Hein, Don and P. Sangkhanukit. Report on the Excavation of the Ban Tao Hai Kilns Phitsanulok, Thailand. Research Centre for Southeast Asian Ceramics Papers No. 1. Adelaide: University of Adelaide and Art Gallery of South Australia, 1984

Hein, Don, Mike Barbetti, and Thongsa Sayavongkhamdy. An Excavation at the Sisattanak Kiln Site, Vientiane Lao P.D.R. Sydney: NWG Macintosh Centre for Quarternary Dating, University of Sydney, 1989.

Helliwell, Christine. "Never Stand Alone": A Study of Borneo Sociality. Phillip, ME: Borneo Research Council, Inc., 2001.

Hering, B.B., ed. Pramoedya Ananta Toer 70 Tahun: Essays to Honour Pramoedya Ananta Toer's 70th Year. Yayasan Kabar Seberang, 1995.

- Mohammed Hoesni Thamrin and His Quest for Indonesian Nationhood, 1917-1941. Yayasan Kabar Seberang, 1996.

Hewison, Kevin. Bankers and Bureaucrats: Capital and the Role of the State in Thailand. New Haven, CT: Yale University Southeast Asian Studies, 1989.

Hill, David and Krishna Sen. The Internet in Indonesia's New Democracy. London: Routledge, 2005.

Hill, Hal, ed. Unity and Diversity: Regional Economic Development in Indonesia since 1970. Singapore: Oxford University Press, 1989.

. Indonesia's Industrial Transformation. Singapore: Institute of Southeast Asian Studies, 1997

Hilsdon, Anne-Marie. Madonnas and Martyrs: Militarism and Violence in the Philippines. St Leonard's, N.S.W.: Allen \& Unwin, 1995.

Hooker, Virginia Matheson. Writing a New Society: Social Change through the Novel in Malay. Sydney: Allen \& Unwin, 2000.

Hooker, Virginia and Barbara Watson Andaya. The Precious Gift/Raja Ali Haji ibn Abmad: An Annotated Translation. Kuala Lumpur: Oxford University Press, 1982.
Howell, Julia Day and Martin van Bruinessen, eds. Sufism and the "Modern" in Islam.

London: St Martins Press, 2007.

Migration, Urbanization and Development in Indonesia. New York: United Nations, 1981.

Graeme, et al. The Demographic Development in Indonesian Development. Singapore: Oxford University Press, 1987.

The Relation of Economic Class and Fertility:

Hull, Terrence H. and Valerie E.J. Hull. The Relation of Economic Institute, Gadjah An Analysis of Some Indonesi Mada University, 1976.

Hull, Terence H., Gavin Jones, and Endang Sulistyaningsih. Prostitution in Indonesia: Its History and Evolution. Jakarta: Pustaka Sinar Harapan, 1999.

列 Ithaca: Cornell University Press, 1998.

leto, Reynaldo C. Pasyon and Revolution: Popular Movements in the Phili 1840-1910. Quezon City: Ateneo de Manila University Press, 1979. 1927-1934.

Ingleson, John. Road to Exile: The Indonesian Nationalist Moveralia, 1979. Singapore: Asian Studies Association of Australia, 1979 Colonial Java, 1906-1926. - In Search of Justice: Workers and Unions in Colonial

Singapore: Asian Studies Association of Australia, 1986 . Jackson, Peter A. Buddhadas

Siam Society, 1988. Books, 1995.

Jenkins, David. Suharto and His Generals. Ithaca: Cornell Modern Indonesia Project, Cornell University, 1984.

Johns, Anthony H. "Indonesian Studies in Australia: An Open Horizon" 1964. Lecture, The Australian National University, Canberra, 30 Junerra: Centre of . The Gift Addressed to the Spirit of the Prophet. Can

Oriental Studies, The Australian National University, 1 collection of Essays on Modern Cultural Options and the Role of Tradition: A Collection of Essays ondies with Indonesian and Malaysian Literature. Canberra: Faculty of Asian Studies with the ANU Press, 1979.

Johns, Anthony H. and Nelly Lahoud, eds. Islam in World Politics. London: Routledge, 2005.

Johns, Yohanni. Bahasa Indonesia: Langkah Baru, A New Approach. Canberra: The Australian National University Press, 1976-90.

Australian National Univer Transition in Asia. Singapore: Maruzen Asia, 1984. Jones, Gavin. The Demographic Transition in Asia. Singapore: Maruzen Asias . Marriage and Divorce in Islamic Southeast Asia. Melbourne: Oxford University Press, 1994

Kahn, Joel S. Constituting the Minangkabau: Peasants, Culture and Modernity in

Colonial Indonesia. Providence: Berg, 1993. . Other Malays: Nationalism and Cosmopolitan 
Kartomi, Margaret J. Matjapat Songs in Central and West Java. Canberra: The Australian National University Press, 1973.

Kaur, Amarjit. Economic Change in East Malaysia: Sabah and Sarawak since 1850. New York: St. Martin's Press, 1998.

Kessler, Clive S. Islam and Politics in a Malay State, Kelantan, 1838-1969. Ithaca: Cornell University Press, 1978.

Kingsbury, Damien. The Politics of Indonesia. Melbourne: Oxford University Press, 1 st ed. 1998; 2nd ed. 2002.

- South-East Asia: A Political Profile. Melbourne: Oxford University Press, 1st ed. 2001; 2nd ed. 2005.

Kumar, Ann. Surapati, Man and Legend: A Study of Three Babad Traditions. Leiden: E.J. Brill, 1976.

. The Diary of Javanese Muslim: Religion, Politics and the Pesantren, 1883-1886. Canberra: Faculty of Asian Studies, The Australian National University, 1985.

Laffan, Michael Francis. Islamic Nationhood and Colonial Indonesia: The Umma below the Winds. London: Routledge, 2003.

Lane, Max. Unfinished Nation: Indonesia before and after Suharto. London: Verso, 2008.

Langlois, Anthony J. The Politics of Justice and Human Rights: Southeast Asia and Universalist Theory. Cambridge: Cambridge University Press, 2001.

Legge, John. Central Authority and Regional Autonomy in Indonesia: A Study in Local Administration, 1950-1960. Ithaca: Cornell University, 1961.

- Indonesia. Englewood: Prentice Hall, 1964.

Sukarno: A Political Biography. London: Allen Lane, 1972.

Legge, John D. and Herbert Feith. "J.A.C. Mackie: Biographical Notes; I. Kandy to Monash". In Observing Change in Asia: Essays in Honour of J.A.C. Mackie, edited by Ron J. May and William J. O'Malley. Bathurst: Crawford House Press, 1989.

Leigh, Barbara. The Changing Face of Malaysian Crafts: Identity, Industry, and Ingenuity. Kuala Lumpur: Oxford University Press, 2000.

Leigh, Michael. The Rising Moon: Political Change in Sarawak. Sydney: Sydney University Press, 1974

Lewis, E. Douglas. People of the Source: The Social and Ceremonial Order of Tana Wai Brama on Flores. Dordrecht: Foris Publications, 1988.

Li, Ta Na. Nguŷēn Cochinchina: Southern Vietnam in the Seventeenth and Eighteenth Centuries. Ithaca: Cornell University, Southeast Asia Program, 1998.

Lindsay, Jennifer. Javanese Gamelan. Kuala Lumpur: Oxford University Press, 1979 2nd ed., 1992.

- Klasik, Kitsch, Kontemporer: Sebuah Studi tentang Seni Petunjukan Jawa. Yogyakarta: Gadjah Mada University Press, 1991.

— trans. Sidelines: Writings from Tempo, Indonesia's Banned Magazine/Goenawan Mohamad. South Yarra, Vic: Hyland House, 1994. trans. Conversations with Difference: Essays from Tempo Magazine/Goenawan Mohamad. Jakarta: PT Tempo Inti Media, 2002.

Lindsay, Jennifer, R.M. Soetanto, Alan H. Feinstein. A Preliminary Descriptive Catalogue of the Manuscripts of the Kraton Yogyakarta. Yogyakarta: Proyek Mikrofilm Kraton Yogyakarta, 1987.

Lindsay, Jennifer, R.M. Soetanto, Alan H. Feinstein, and T.E. Behrend. Kraton Yogyakarta. Jakarta: Yayasan Obor Indonesia, 1994.

Lindsey, Timothy, ed. Indonesia: Law and Society. Annandale: Federation Press, 1 st ed. 1999; 2nd ed. 2008.

Lindsey, Timothy and Howard Dick, eds. Corruption in Asia: Rethinking the Governance Paradigm. Annandale: Federation Press, 2002.

W.W. Vietnamese-English Archaeological Glossary with English Index. Canberra: Faculty of Asian Studies, The Australian National University, 1970.

Conflict in Rural Java. Berkeley: Center for South and Southeast Asian Studies, The University of California, 1970.

Lucas, Anton. One Soul, One Struggle: Region and Revolution in Indonesia. Sydney: Allen \& Unwin, 1991.

MacIntryre, Andrew J. Business and Politics in Indonesia. Allen \& Unwin, 1991.

Mackie, J.A.C. Konfrontasi: The Indonesia-Malaysia dispute, 1963-1966. Kuala Lumpur: Oxford University Press, 1974.

The Chinese in Indonesia: Five Essays. Melbourne: Australian Institute of International Affairs. 1976

Macknight, C.C. The Voyage to Marege': Maccassan Trepangers in Northern Australia. Melbourne: University of Melbourne Press, 1976.

Manning, Chris. Indonesian Labour in Transition: An East Asian Success Story? Cambridge: Cambridge University Press, 1998.

Marr, David G. Vietnamese Anticolonialism, 1885-1925. Berkeley: University of California Press, 1971.

. Vietnamese Tradition on Trial, 1920-1945. Berkeley: University of California Press, 1981.

- Vietnam 1945: The Quest for Power. Berkeley: University of California Press, 1995.

Martyn, Elizabeth. Women's Movement in Postcolonial Indonesia: Gender and Nation in a New Democracy. London: RoutledgeCurzon, 2005.

Maxwell, John. Soe Hok-Gie: Pergulatan Intelektual Muda Melawan Tirani. Jakarta: P.T. Pusaka Grafiti, 2001.

Maxwell, John, Ron J. May, and William J. O'Malley. "J.A.C. Mackie: Biographical Notes: II The Canberra Years". In Observing Change in Asia: Essays in Honour f I Mackie, edited by Ron J. May and William J. O'Malley. Bathurst: Crawford House Press, 1989.

Tration, Trade and Transformation. Austalian National Gallery. Melbourne: Oxford University Press, 1990. 
Sari to Sarong: Five Hundred Years of Indian and Indonesian Textile Exchange. Canberra: The National Gallery of Australia, 2003.

McDonald, Hamish. Suharto's Indonesia. Blackburn,Vic.: Fontana/Collins, 1980.

McDonald, Peter, ed. Pedoman Analisa Data Sensus Indonesia, 1971-1980. Canberra: Australian Vice-Chancellors' Committee, Universities International Development Program, 1983.

McLaren, Anne. "Report on Asian Languages Enrolments in Australian Higher Education, 2006-07". For the Asian Studies Association of Australia, 10 April 2008, available at <http://www.griffith.edu.au/__data/assets/pdf_ file/0008/145790/ASAA-Language-Stats-Summative-Report-April-2008.pdf>.

McWilliam, Andrew. Paths of Origin, Gates of Life: A Study of Place and Precedence in Southwest Timor. Leiden: KITLV Press, 2003.

Mearns, David and Christopher J. Healey, eds. Remaking Maluku: Social Transformation in Eastern Indonesia. Darwin: Northern Territory University, 1996.

Miharja, Achdiat. Atheis. Melaka: A. Bandong, 1966.

Miles, Douglas. Cutlass and Crescent Moon: A Case Study of Social and Political Change in Outer Indonesia. Sydney: Centre for Asian Studies, 1976.

Milner, Anthony C. Kerajaan: Malay Political Culture on the Eve of Colonial Rule. Tucson: Arizona Press, 1982.

Morrell, Elizabeth. Securing a Place: Small-Scale Artisans in Modern Indonesia. Ithaca: Southeast Asia Program Publications, Cornell University, 2005.

Mortimer, Rex. The Indonesian Communist Party and Land Reform: 1959-1965. Monash Papers on Southeast Asia, no. 1. Clayton: Monash University, 1972. , ed. Showcase State: the Illusion of Indonesia's Accelerated Modernisation. Sydney: Angus \& Robertson, 1973.

. Indonesian Communism under Sukarno, Ideology and Politics, 1959-1965. Ithaca: Cornell University Press, 1974

Morwood, M. J. and Penny Oosterzee. The Discovery of the Hobbit: The Scientific Breakthrough that Changed the Face of Human History. Milsons Point: Random House, 2007.

Nurmila, Nina. Women, Islam and Everyday Life: Renegotiating Polygamy in Indonesia. London: Routledge, 2009.

Oakman, Daniel. Facing Asid: A History of the Colombo Plan. Canberra: Pandanus Books, ANU, 2004.

O'Connor, Sue and Peter Veth, eds. East of Wallace's Line: Studies of the Past and Present Maritime Cultures of the Indo-Pacific Region. Rotterdam: A.A. Balkema, 2000.

O'Connor, Sue, Matthew Spriggs, and Peter Veth. The Archaeology of the Aru Islands, Eastern Indonesia. Canberra: Pandanus Books, The Australian National University, 2005.

Osborne, Milton E. The French Presence in Cochinchina and Cambodia: Rule and Response, 1859-1905. Ithaca: Cornell University Press, 1969.

Southeast Asia: An Introductory History. Sydney: Allen \& Unwin, 1979a.
Before Kampuchea: Preludes to Tragedy. Sydney: Allen \& Unwin, $1979 b$. Future. New York: Atlantic Monthly The Mekon

Press, 2000.

O'Shaughnessy, Kate. Gender, State and Social Power: Divorce in Contemporary Indonesia. London: Routledge, 2009.

Pecollections of an Indonesian Diplomat in the Sukarno Era, Ganis Harsono. St. Lucia: University of Queensland Press, 1977.

Penders, C.L.M. and Ulf Sundhaussen. Abdul Haris Nasution: A Political Biography. St. Lucia: University of Queensland Press, 1985.

Perri Singarimbun. Population and Poverty in Rural Java: Some Ariharjo. Ithaca: Cornell International Agriculture Economic Arithmetic

Monograph, 1973.

Polomka, Peter. Indonesia since Sukarno. Harmondsworth: Penguin Books, 1971.

Proudfoot, Ian. Early Malay Printed Works. Kuala Lumpur: University of Malaya, 1993.

Old Muslim Calendars of Southeast Asia. Leiden: Brill, 2006.

anese: Aspects of Its Social and Literary Character. Leiden: KITLV Press, 1992.

Leinte System. Singapore: Oxford University Press, 1985.

The Contest for North Sumatra: Atjeh, the Netherlands and Britain 1858-1898. London: Oxford University Press, 1969.

1858-1898. London: Oxford University Press, 1969. Fuditional Rule in . The Blood of the People: Revolution and the End of Traditiona 1974.

Northern Sumatra. Kuala Lumpur: Oxford University Press, 1974. - Southeast Asia in the

University Press, 1988-93. - "Anthony Hearle Johns with 'List of A.H. John's Publications" An Anthony Essays on Scripture, Thought \& Society: A Festschrift in Honour of Anthor

H. Johns, edited by Peter G. Riddell and Tony Street. Leiden: Brill, -. "Indonesian Studies

no. 1 (2009): 50-74. Reid, Anthony and Lance Castles, eds. Pre-Colonial State Systems in Southeast Asid 1975.

Kuala Lumpur: The Malaysian Branch of the Royal Asiatic Society and Society in the Reuter, Thomas. Custodians of the Sacred Mountains: Culture and Soc

Highlands of Bali. Honolulu: University of Hawain Dualism in Highland Balinese The House of Our Ancestors: Precede

Society. Leiden: KITLV Press, 2002b. The Real Face of Thai Feudalism Today. Reynolds, Craig J. Thai Radical Discourse: The Real Face of Thai Fendalist 1987.

Ithaca: Cornell University Modern Southeast Asia Program, 1987 various editions, Ricklefs, Merle. A History of Modern Indonesia. London: Macmillan, various editions, 1981-90. 
War, Culture and Economy in Java, 1677-1726. Sydney: Allen \& Unwin, 1993.

-. The Seen and Unseen Worlds in Java, 1726-1749: History, Literature and Islam in the Court of Pakubuwana II. Sydney: Allen \& Unwin, 1998.

Riddell, Peter. 'Abdul al-Ra'üf Al-Singilì's Rendering into Malay of the Jalalayn Commentary: Transferring a Tradition. Berkeley: Centers for South and Southeast Asian Studies, University of California, 1990.

Robinson, Kathryn. Stepchildren of Progress: The Political Economy of Development in an Indonesian Mining Town. Albany: State University of New York Press, 1986.

- "Chandra Jayawardena and the Ethical 'Turn' in Australian Anthropology". Critique of Anthropology 24, no. 4 (2004): 379-402.

-. "We the Ethnographers". In The Coombs: A House of Memories, edited by Brij V. Lal and Allison Ley. Canberra: Research School of Pacific and Asian Studies, The Australian National University, 2006

- "Anthropology of Indonesia in Australia: The Politics of Knowledge". RIMA 43, no. 1 (2009a): 7-33.

Gender, Islam and Democracy in Indonesia. London: Routledge, 20096.

Robison, Richard. Indonesia: The Rise of Capitalism. London: Allen \& Unwin, 1986. - Reorganizing Power in Indonesia: The Politics of Oligarchy in an Age of Markets. New York: Routledge, 2004.

Robison, Richard and Garry Rodan. The Political Economy of South-East Asia: An Introduction. Melbourne: Oxford University Press, 1997.

Robson, Stuart. Hikajat Andaken Penurat. The Hague: Nijhoff, 1969.

- Patterns of Variation in Colloquial Javanese. Monash: Centre for Southeast Asian Studies, 1991.

- Deśawarnana (Nāgarakrtāgama) by Mpu Prapañca. Leiden: KITLV Press, 1995.

Rodan, Garry. The Political Economy of Singapore's Industrialization: National State and International Capital. Basingstoke: Macmillan, 1989.

Rodan, Garry, Richard Robson, and Kevin Hewison, eds. The Political Economy of South-East Asia: Markets, Power and Contestation. 3rd ed. Melbourne: Oxford University Press, 2006.

Roff, William. The Origins of Malay Nationalism. New Haven: Yale University Press, 1967.

Sakai, Minako, Glenn Banks, and J.H. Walker, eds. The Politics of the Periphery in Indonesia: Social and Geographical Perspectives. Singapore: NUS Press, 2009.

Santoso, Soewito. Sutasoma: A Study in Javanese Wajrajana. New Delhi: International Academy of Indian Culture, 1975.

Sarumpaet, J.P and Jamie Mackie. Introduction to Bahasa Indonesia. Melbourne: Melbourne University Press. 1967.

Sen, Krishna. Indonesian Cinema: Framing the New Order. London: Zed Books, 1994.
Schiller, James. Developing Jepara: State and Society in New Order Indonesia. Clayton:

Monash Asia Institute, 1996.

Mocial and Economic Studies in Development.

Canberra: Australian National University Press. 1967

Canberra: Australian Nevelopment of Thai Agriculture. Ithaca: Cornell University

Press, 1970. Singarimbun, Masri. Kinship, Descent and

University of California Press, 1975. The Rhymed Chrole of the Macassar War Skinner, Cyril. Sjair Perang Mengkasar: The Rhymed

by EntjiAmin. The Hague: M. Nijhoff, 1963.

Branch, Royal Asiatic Society, 1966.

Branch, The Book of Cabolèk. The Hague: Martinus Nijhoff, 1975.

Arjunawijaya: A Kakawin of Mpu Tantalar. The Hague: Martinus Nijhoff, 1977.

Stacey, Natasha. Boats to Burn: Bajo Fishing Activity in the Australian Fishing Zone. Canberra: ANU E Press, 2007.

Maila Matriliny and Modernity: Sexual Politics and Social Change in Rural Malaysia. St Leonard's, N.S.W: Allen \& Unwin, 1996

Malasia. St Le Politics and Society of the Lao Stuart-Fox, Martin, ed. Contemporary Laos, Studies in the Politios and Soc Press. 1982.

People's Democratic Republic. St Lucia: University 2010.

The A to $Z$ of Laos. Lanham: Scarecrow Press Gender Relations in Urban Java. Sullivan, Norma. Masters and Managers: A Study of

St Leonard's, N.S.W.: Allen \& Unwin, 1994. Sundhaussen, Ulf. The Road to Power:

Oxford University Press, 1982. Sutherland, Heather. The Making of a Bureaucratic Elite: The Colonial Transform 1979. of the Javanese Priayi. Singapore: Asian Studies Association or Australia, 1965.

Swift, Michael G. Malay Peasant Society in Jelebu. London: Athiddle Class Indonesia. Tanter, Richard and Kenneth Young, eds. The Politics of Middle Class Indon

Clayton: Monash University, Centre of Southeast Asian Studies, 1900 Thailand.

Tapp, Nicholas. Sovereignty and Rebellion: The

Singapore: Oxford University Press, 1989.

Tarling, Nicholas. Anglo-Dutch Rivalry in the

University of Queensland Press, 1962 . - Piracy and Politics in the Malay World: A Study of British 1963.

Nineteenth-Century South-east Asia. Melbourne: F.W. Cheshire, 1963. Originally - A Concise History of Southeast Asia. New

published as Southeast Asia, Past and Present. , ed. The Cambrid

University Press, 1992. Taylor, Jean G. The Social World of Batavid: European and Eurasian 2009. 
Taylor, Philip. Fragments of the Present: Searching for Modernity in Vietnam's South. St Leonards, N.S.W.: Allen \& Unwin, 2001.

- Goddess on the Rise: Pilgrimage and Popular Religion in Vietnam. Honolulu: University of Hawai'i Press, 2004.

Cham Muslims of the Mekong Delta: Place and Mobility in the Cosmopolitan Periphery. Singapore: NUS Press, 2007.

Trocki, Carl. Opium and Empire: Chinese Society in Colonial Singapore, 1800-1910. Ithaca: Cornell University Press, 1990.

Singapore: Wealth, Power, and the Culture of Control. New York: Routledge, 2006.

Vickers, Adrian. Bali: A Paradise Created. Berkeley: Periplus, 1989.

Being Modern in Bali: Image and Change. New Haven: Yale University Southeast Asia Studies, 1996.

- Journeys of Desire: A Study of the Balinese Malat. Leiden: KITLV Press, 2005.

Walker, Andrew. The Legend of the Golden Boat: Regulation, Trade and Traders in the Borderlands of Laos, Thailand, China and Burma. Richmond: Curzon, 1999.

Ward, Ken. The 1971 Election in Indonesia: An East Java Case Study. Clayton: Centre for Southeast Asian Studies, Monash University, 1974.

Warr, Peter G., ed. The Thai Economy in Transition. Cambridge: Cambridge University Press, 1993.

Warren, Carol. Adat and Dinas: Balinese Communities in the Indonesian State. Kuala Lumpur: Oxford University Press, 1993.

Warren, James F. The Sulu Zone: 1768-1898: The Dynamics of External Trade, Slavery and Ethnicity in the Transformation of a Southeast Asian Maritime State. Singapore: Singapore University Press, 1981.

Webb, R.A.F. Paul. Palms and the Cross: Socio-economic Development in Nusatengrara, 1930-1975. Townsville: James Cook University of Northern Queensland, Centre for South East Asian Studies, 1986.

Whittaker, Andrea. Intimate Knowledge: Women and their Health in North-east Thailand. St Leonard's, N.S.W.: Allen \& Unwin, 2000. 2004.

Wijeyewardene, Gehan. Place and Emotion in Northern Thai Ritual Behaviour Bangkok: Pandora, 1986.

Worsley, Peter. Babad Buleng: A Balinese Dynastic Genealogy. The Hague: Nijhoff, 1972.

\section{SOUTHEAST ASIAN STUDIES IN THE U.S. Construction of Traditions of an Autonomous History, Its Limitations, and Future Tasks}

\author{
Song Seung-Won
}

\section{INTRODUCTION}

This chapter examines the current state and future objectives of Southeast Asian Studies in the U.S. The U.S. is a leading country in terms of Southeast Asian Studies within the general field of area studies. Area studies began to assume importance in the U.S. in the context of American concerns about the expansion of Third Word Communism during the Cold War period. Amidst this tense international atmosphere, Southeast Asianists in pe U.S set themselves against what they considered to be the limitations of European colonial studies preoccupied with the Western presence and in Southeast Asia and the reconstruction of the history and cultural traditions of those whom they governed. They instead focused more on the circumstances of modern Southeast Asia, post-colonial nation-building and the prospects and problems for socio-economic and political development. Some region from local perspectives and to construct an autonomous history of 